Canadian Science Publishing

Canadian Journal of Earth Sciences Revue canadienne des sciences de la Terre

\title{
Sedimentary Exhalative Origin for Magnetite Deposits of the New Jersey Highlands
}

\begin{tabular}{|r|l|}
\hline Journal: & Canadian Journal of Earth Sciences \\
\hline Manuscript ID & cjes-2017-0004.R1 \\
\hline Manuscript Type: & Article \\
\hline Date Submitted by the Author: & O2-May-2017 \\
\hline Complete List of Authors: & $\begin{array}{l}\text { Matt, Peter; Brooklyn College, Earth and Environmental Science } \\
\text { Powell, W.; Dept of Geology } \\
\text { Volkert, Richard; New Jersey Geological Survey } \\
\text { Gorring, Matthew; Department of Earth and Environmental Sciences } \\
\text { Johnson, Al; Brooklyn College, Earth and Environmental Science }\end{array}$ \\
\hline $\begin{array}{r}\text { Is the invited manuscript for } \\
\text { consideration in a Special } \\
\text { Issue? : }\end{array}$ & N/A \\
\hline Keyword: & magnetite, Grenville Province, iron formation, back-arc basin, New Jersey \\
\hline &
\end{tabular}




\section{Sedimentary Exhalative Origin for Magnetite Deposits of the New Jersey} Highlands

Peter Matt, Wayne Powell, Richard Volkert, Matthew Gorring and Al Johnson

\section{ABSTRACT}

6 The New Jersey Highlands and contiguous Hudson (New York) Highlands host hundreds of

7 small, worked-out magnetite mines, and the major zinc-oxide deposits of Franklin and Sterling

8 Hill. The origin of the magnetite ore remains controversial. Two temporally distinct genetic

9 models have been proposed for magnetite: 1) a pre-Ottawan, sedimentary exhalative model in

10 which ores were deposited on the sea floor as precipitates from iron-enriched hydrothermal

11 fluids; 2) a late Ottawan, fluid alteration model in which the current mineral composition of ores

12 was derived from Fe-rich, alkaline fluids, associated with late episodes of granitic plutonism

13 (Low-Ti Kiruna-type deposits), or in which deposits derived from metamorphogenic fluids

14 circulating in a regional shear zone leached metals from host rocks and precipitated them in

15 veins and faults. Detailed mapping of ore deposits and host rocks near Wanaque, NJ,

16 Ringwood, NJ and Warwick, NY reveal that ore bodies are hosted by supracrustal rocks

17 deposited in a back-arc basin. At Wanaque and Warwick, ores are strataform and stratabound.

18 Discordant ore bodies at Ringwood are associated with a feeder zone, presumed to have

19 intersected the paleosurface at a steep angle. Sharply-layered quartz-diopside gneiss is

20 spatially associated with ore at Wanaque and Warwick, and massive diopsidite is spatially

21 associated with ore at all three locations. Diopsidite in these rocks is non-aluminous, iron-

22 enriched and shares these characteristics with modern metalliferous sediments. Massive

23 diopsidite and quartz-diopside gneiss are interpreted to be metamorphosed carbonate facies

24 iron formation, and associated magnetite to be metamorphosed oxide-facies iron formation. 


\section{Introduction}

Magnetite deposits are common in the New Jersey Highlands and contiguous

30 Hudson Highlands of New York, Appalachian inliers of the Grenville Province (Fig. 1).

31 They are also abundant in the Adirondack Highlands, the southeastern extremity of the

32 contiguous Grenville Province (Fig. 1). Over 400 deposits have been documented in

33 New Jersey (Peck 2009), including the relatively large past-producing Edison, Andover,

34 and Dover mines (Fig. 2). However, given the diversity of age and composition of host

35 rocks, the genesis of this group of ore deposits has remained controversial. Numerous

36 genetic models have been proposed for the formation of magnetite deposits regionally,

37 but two models that are distinct in terms of process and relative timing during the

38 Grenville Orogenic Cycle (McLelland 1996) are predominant: 1) late to post-orogenic

39 magmatic or metamorphogenic; and 2) early orogenic, syn-depositional exhalative.

40 The late- to post-orogenic model was developed, in part, based on deposits from

41 the magnetite mining district of the eastern Adirondack Highlands (McLelland et al.

42 2001; McLelland et al. 2002; Valley et al. 2011). Many mines in this area are hosted by

43 the Lyon Mountain granite, a rock which lacks widespread penetrative deformation. On

44 this basis, its crystallization age of $1060-1050 \mathrm{Ma}$ is understood to coincide with the end

45 of the Ottawan orogeny in the Adirondack Highlands (Valley et al. 2011). Subsequent to

46 formation of these deposits, and presumably coincident with intrusion of the granite, the

47 ores were pervasively altered by two or three pulses of alkali-rich hydrothermal fluid

48 (Valley et al. 2011). Associated hydrothermal zircons have permitted dating of Na-

49 alteration at 20-60 Ma after granite crystallization (Valley et al. 2011). Oxygen isotope 
50 studies of quartz-magnetite pairs from multiple locations suggest that these minerals

51 equilibrated with hydrothermal fluids between 565 and $675^{\circ} \mathrm{C}$ (McLelland et al. 2001;

52 McLelland et al. 2002). Although formulated based on Adirondack deposits, this model

53 has been applied to the interpretation of iron ores of New Jersey (Foose 1995)

54 Magnetite mineralization at the Hogencamp, Pine Swamp and other nearby

55 mines in the Hudson Highlands also has been interpreted to have occurred late in the

56 Grenville Orogenic Cycle (Kalczynski and Gates 2014). In this area, two 3-5 km long

57 veins of massive magnetite occur within a regional shear zone. Alteration zones

58 separate the mineralized veins from unaltered rocks. Geochemical analysis of the veins

59 and surrounding rocks led the authors to conclude that acidic, iron-rich metamorphic

60 fluids introduced into shear zones caused exchange reactions with country rocks and

61 precipitated magnetite in the centres of the veins (Kalczynski and Gates 2014).

62 Although timing of this event is not well-constrained, Gates (1995) inferred a post-

63 Ottawan age based on the retrograde parageneses associated with mylonitic fabric and

64 brittle failure of rocks within the shear zone (Garrels and McKenzie 1971; Gates 1995).

65 In contrast, an early-orogenic, sedimentary exhalative (sedex) model has been

66 proposed for carbonate-hosted zinc and magnetite deposits in the New Jersey

67 Highlands (Johnson et al. 1990; Johnson and Skinner 2003; Peck 2009). Johnson et al.

68 (1990) found that calcite within mineralized layers of the host Franklin Marble has lower

$69 \delta^{18} \mathrm{O}$ than calcite in unmineralized layers, leading to the conclusion that isotopic

70 character was controlled by whole rock mineral modes. Their isotopic measurements

71 were successfully replicated by models using assumed mineral protoliths with values

72 adjusted for metamorphic devolatilization. The models indicated equilibrium between 
73 protolith minerals and hydrous fluid at $150^{\circ} \mathrm{C} \pm 50^{\circ} \mathrm{C}$. This fluid must have been

74 principally seawater to account for the unusually oxidative character of the Sterling Hill

75 and Franklin Furnace zinc deposits.

$76 \quad$ Later work on the Franklin Furnace magnetite deposit and spatially associated

77 magnetite deposits along strike further support a seafloor, or sub-seafloor, hydrothermal

78 origin. Isotopic measurements of $\mathrm{O}$ and $\mathrm{C}$ in calcite and $\mathrm{O}$ in magnetite remained

79 consistent with the earlier modeling, confirming the presumed equilibration with

80 hydrothermal fluid at $\sim 150^{\circ} \mathrm{C}$ (Johnson and Skinner 2003). The authors noted that

81 measured values of $\delta^{18} \mathrm{O}$ and $\delta^{13} \mathrm{C}$ at the Franklin Furnace deposit are within the range

82 reported for Superior-type banded iron formations.

83 Peck et al. (2009) studied the isotopic and petrologic character of 15 other

84 carbonate or skarn-hosted magnetite deposits in the New Jersey Highlands, as well as

85 new samples from Franklin Furnace. Their isotopic measurements supported a model

86 for fluid-rock equilibration at temperatures between 125 and $175^{\circ} \mathrm{C}$. Peck et al. (2009)

87 presented additional evidence for the presence of a hydrothermal/volcanic centre in the

88 western NJ Highlands during the Mesoproterozoic. This evidence includes the

89 occurrence of a high-Mg, orthoamphibole gneiss (metamorphosed alteration zone)

90 between the Sterling Hill and Andover mining districts (Fig. 2) and a trend of increasing

91 alteration in bimodal metavolcanic rocks with proximity to magnetite deposits (Peck

92 2009).

93 Timing of the deposition of these carbonate-hosted orebodies of the western NJ

94 Highlands is constrained to the period $1.3-1.25 \mathrm{Ga}$, based on U-Pb dating of zircons

95 from meta-rhyolite intercalated with the Franklin Marble (Volkert et al. 2010). This time 
96 period broadly coincides with the Elzeverian orogeny of the Grenville Orogenic Cycle

97 (McLelland 1996), and an associated episode of back-arc extension (Chiarenzelli et al. 98 2011).

99 The distinctly different models of ore genesis described above have influenced 100 the interpretation of the less-studied, non-carbonate-hosted iron deposits of the New 101 Jersey Highlands. Syngenetic, magmatic, and metamorphogenic models have all been 102 invoked to account for these deposits. Puffer (2001) noted that these orebodies are 103 associated with a diversity of host rocks, and suggested that the lithologic character of 104 the deposit hosts could provide insight into deposit geneses. Based on this, Puffer 105 (2001) proposed that there could be as many as five distinct magnetite mineralization 106 styles/events in the region.

107 Although the character of the host rock lithologies of New Jersey Highlands 108 magnetite deposits is variable, the modest geographical range and limited variation in 109 ore composition suggests that there may be common processes that formed many of 110 these deposits. Accordingly, this study focuses on three small magnetite deposits, each 111 associated with distinct lithological hosts: 1) stratiform, metasedimentary-associated 112 deposits (Roomy and Blue mines) in Wanaque, $\mathrm{NJ}$; 2) a stratiform, metavolcanic113 associated deposit in Warwick, NY (Miles Standish mine); and 3) a non-stratiform 114 basement-hosted deposit in Ringwood, NJ (Hickory Valley and Hickory Mountain 115 deposits) (Fig. 3). The objective was to determine if each of these lithologically distinct 116 deposits was produced by a different mineralizing processes, or whether a common 117 model could account for their genesis. 
119 Bedrock Geology and Geochronology of the New Jersey Highlands

120 The New Jersey Highlands is a 24-32 km wide by $88 \mathrm{~km}$ long belt of

121 Mesoproterozoic metamorphic rocks stretching from the Delaware River near Easton,

122 PA, northeast to the New York state line (Fig. 1). The Highlands are in fault contact with

123 Mesozoic rocks of the Newark basin to the east, and Paleozoic sedimentary rocks of the

124 Appalachian Valley and Ridge province to the west. A Paleozoic graben in the central 125 part of the Highlands separates the region into eastern and western parts.

126 The Losee Metamorphic Suite, a group of metavolcanic to metaplutonic rocks

127 with a compositional range from mafic to felsic, constitutes the basement of the New

128 Jersey Highlands. Felsic rocks have dacitic to tonalitic protoliths (Puffer and Volkert

129 1991). Intermediate rocks are locally charnockitic (Volkert and Drake 1999).

130 Volumetrically minor amphibolites in the suite are predominantly calc-alkaline, and have

131 basaltic to basaltic andesitic protoliths (Volkert et al. 2010). Losee Suite rocks range in

132 age from $1366 \pm 9$ to $1248 \pm 12 \mathrm{Ma}$, a time span during which magmatism may have been

133 continuous or episodic (Volkert et al. 2010). Volkert (2004) considers the Losee Suite to

134 be part of a continental arc that formed at the southeastern edge of Laurentia prior to 135 the assembly of Rodinia.

136 Supracrustal rocks formed in a back-arc basin inboard of the Losee arc (Volkert 137 and Drake 1999). These rocks are metasedimentary (marble, quartzite, felsic gneisses 138 and calc-silicate gneisses) and metavolcanic (amphibolite and meta-rhyolite).

139 Metapelitic rocks are rare. Volkert and Drake (1999) used a multi-component analysis

140 of major elements to infer that felsic gneisses originated as immature sandstones 141 sourced from an active continental margin, whereas calc-silicate gneisses were derived 
142 from immature island arc sediments. Marble was metamorphosed from shallow marine

143 limestones. Supracrustal amphibolites are meta-basalts with a range of affinities, from

144 MORB-like, to E-MORB-like, to island-arc-like. Meta-rhyolites of arc affinity overlie the

145 Franklin marble in the western Highlands (Volkert et al. 2010). Intermediate

146 metavolanic rocks are lacking among NJ Highlands supracrustals. This variety of

147 lithologies and their inferred protoliths supports the interpretation of a back-arc basin 148 tectonic setting.

149 Deposition of the Franklin marble and associated zinc ore is constrained to the 150 period $\sim 1295-1300$ Ma by SHRIMP zircon ages of intercalated metarhyolites, (Volkert et

151 al. 2010). A metarhyolite from beneath the structurally higher Wildcat marble was dated

152 at $1259 \pm 7 \mathrm{Ma}$. These ages overlap with those of younger members of the Losee

153 basement suite, $\sim 1248-1282 \mathrm{Ma}$, but are significantly younger than the oldest basement

154 rocks, $\sim 1363-1366 \mathrm{Ma}$ (Volkert et al. 2010). These data suggest that following an initial

155 episode of arc magmatism, new crust of continental arc affinity was created

156 concurrently with deposition of eroded arc products, arc-derived volcanic rocks and 157 chemical sediments.

158 Monzonitic to leucogranitic rocks of the Vernon Supergroup were emplaced at $159 \sim 1185 \mathrm{Ma}$ (Volkert et al. 2010). These metaluminous to peraluminous A-type granites 160 are ubiquitous, underlying some $55 \%$ of the Highlands (Volkert and Drake 1999).

161 Weakly foliated to undeformed granitoids of the Mt. Eve suite were emplaced at 162 -1020 Ma, marking the end of Grenville compressional tectonics (Gorring et al. 2004;

163 Volkert et al. 2010). The spatially restricted outcrop of Mt. Eve rocks suggest that 
164 magmas were generated by depressurization melting due to localized extension

165 associated with post-tectonic transpression (Gorring et al. 2004).

166 With the exception of Mt. Eve rocks, Highlands rocks were metamorphosed at 167 upper amphibolite to granulite facies. Peak metamorphic conditions of $\sim 760^{\circ} \mathrm{C}$ at 0.41 -

$1680.50 \mathrm{GPa}$ occurred by $1030 \mathrm{Ma}$ (Vokert 2010) and were associated with the Ottawan 169 orogeny (Volkert and Drake 1999; Johnson and Skinner 2003; Gorring et al. 2004; 170 Volkert 2004; Peck et al. 2006; Peck 2009). Recent geochronology on Highlands rocks

171 shows a variety of metamorphic ages on zircons with clusters at $\sim 1212-1252 \mathrm{Ma}$, 172 -1140-1170 Ma, 1010-1030 Ma, and 989-997 Ma (Volkert et al, 2010). These data 173 support multi-stage histories of Grenville orogenesis (McLelland 1996; Rivers 1997).

174 The youngest dates indicate some post-Ottawan thermal activity (Volkert et al. 2010). 175

\section{Analytical Methods}

Representative samples of mapped units were collected from each of three map

178 sites. A subset of these were thin-sectioned. After petrographic analysis, a final group 179 of 41 unweathered and non-retrograded samples were analyzed for 32 trace elements 180 on the Perkin Elmer Dynamic Reaction Cell-e Inductively Coupled Mass Spectrometer 181 (ICP-MS) at the Brooklyn College Environmental Sciences Analytical Center (Table 2).

182 Samples were crushed to sand-size, then powdered in a Retsch PM-100 ball mill

183 fitted with a tungsten carbide container and balls. Powders were digested in $7 \mathrm{ml}$ Teflon

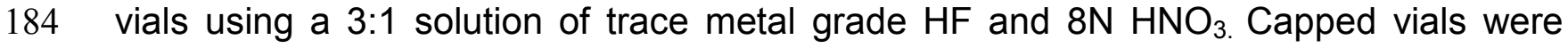
185 heated overnight at $120^{\circ} \mathrm{C}$ and allowed to evaporate the following day. Dry residue was 186 twice dissolved in $8 \mathrm{~N} \mathrm{HNO}_{3}$, heated and evaporated. The samples were then diluted 
187 with $2.5 \mathrm{ml}$ deionized water and $2.5 \mathrm{ml} 8 \mathrm{~N} \mathrm{HNO}_{3}$, capped, heated and checked for 188 clarity. Clear fluids were diluted with $50 \mathrm{ml}$ deionized water for an initial dilution factor of 189 500x. Further dilutions to $2000 x$ and $10000 x$ were made as required for specific 190 analytes.

191 To correct for mass-dependent instrument drift, a matrix-matched drift solution 192 was inserted between every 5 samples in each run. This drift solution was made by 193 mixing digested, 1000x diluted mixed samples of a subset of the rocks examined in this 194 study. USGS standard rock powders GSP-2, BHVO-2, QLO-1, AGV-2, BIR-1 and W-2 195 were analyzed to calibrate instrument output.

196 Ten samples were analyzed for major oxide concentrations on the Horiba JY

197 Ultima C Optical Emission Spectrometer (ICP-OES) at Montclair State University 198 (Table 1). Powders were prepared for analysis using the flux fusion method per MSU 199 protocols: addition of lithium borate flux, transfer of powders to graphite crucibles and 200 heating to $1050^{\circ} \mathrm{C}$ in a muffle furnace for $15-20$ minutes. Melts were diluted to a factor 201 of $500 x$ in $7 \% \mathrm{HNO}_{3}$, then to $4000 \mathrm{x}$ in $2 \% \mathrm{HNO}_{3}$ prior to analysis. An additional six 202 samples were analyzed for major and trace elements at Activation Laboratories in 203 Ancaster, Ontario, Canada, using their analysis package code 4 Litho (Tables 1,2).

204 All samples were analyzed for major oxide concentrations on the Hitachi TM2051000 Scanning Electron Microscope-SEM-EDS at Brooklyn College (Table 1). 206 Powdered samples were compressed and placed in an aluminum stage receptacle. 207 Raster analyses were obtained for a minimum of three $0.5 \mathrm{~mm}^{2}$ areas, and an average 208 composition was calculated. Machine outputs in element weight percent were 
209 converted to oxide weight percent and calibrated to the values obtained at Montclair

210 State for the same powders.

211 Approximately 125 SEM-EDS analyses from polished thin sections of 28 samples

212 were performed to characterize the compositional variability of pyroxene, and to a lesser

213 extent, amphibole and biotite.

214

\section{Descriptions of Mapped Rocks}

216 Brief descriptions of the mapped units (Fig. 4) are provided below. For

217 comprehensive descriptions of the regional bedrock, see Volkert $(1999,2004,2010$,

218 2011). Mapped rocks are divided into four groups: 1) tonalitic gneiss (basement); 2)

219 felsic gneisses; 3) amphibolites; and 4) high-Fe and Fe-altered rocks. A fifth rock,

220 marble (unmapped because of limited outcrop) is also described. Rock units were

221 classified based on mineral assemblages, field relationships, rock textures and

222 geochemical profiles. Rock names are those used on the maps (Fig. 4). All rare earth

223 element abundances have been normalized to the chondritic values of Boynton (1984).

$224 \mathrm{La} / \mathrm{Yb}$ and $\mathrm{La} / \mathrm{Lu}$ are both used as indicators of light/heavy rare earth element

225 abundances because not all rocks referred to herein were analyzed for both $\mathrm{Yb}$ and $\mathrm{Lu}$.

226 However where both elements were analyzed, the two ratios are sufficiently similar to

227 be comparable.

228

229 Tonalitic Gneiss

230 This is a massive, tan- to light grey-weathering, medium-grained, mafic-poor

231 rock. Quartz comprises $10-50 \%$ of the rock, with the majority of the remaining rock 
232 composed of antiperthite and plagioclase. Magnetite, biotite, augite and apatite are 233 accessory constituents. Two samples show marked enrichments in light rare earth

234 elements (LREE), with La/Yb 5.8-8.9 and a distinct, but small positive Eu anomaly (Fig.

235 6). The REE abundances of these samples resemble Losee samples analyzed by 236 Volkert (1999).

237 Metre-scale lenses of amphibolite are common within the tonalitic gneiss. One 238 basement outcrop of amphibolite is significantly larger, with a more massive texture 239 than average. This rock has greater overall REE concentrations and much greater 240 enrichments of LREE, compared to tonalitic gneiss (Fig. 6). However the general shape 241 of its REE curve resembles that of the tonalitic gneiss, suggesting similarity of the 242 magma sources. This suggestion is supported by the close cluster formed by the 243 tonalitic gneiss and basement amphibolite on the discrimination diagram of Winchester 244 and Floyd (Pearce 1996) (Fig.8). The tonalitic gneiss has been mapped by Volkert 245 (2011) as a member of the Losee Metamorphic Suite, the regional basement.

$246 \underline{\text { Marble }}$

247 Unlike the western New Jersey Highlands, marbles are rare in the eastern New 248 Jersey Highland sites described herein. We observed two $\sim 1 \mathrm{~m}$ layers of impure marble, 249 too thin to map, in the Wanaque map area. The marble is composed of $50-80 \%$ calcite, 250 with humite representing most of the balance. Phlogopite and quartz are minor 251 constituents. Marbles have low overall REE abundances, with high fractionation 252 between the LREE- and middle rare earth elements (MREE) (Fig. 6).

$254 \quad$ Felsic Gneisses 
We distinguished 5 felsic gneisses on the basis of principal mafic minerals,

256 feldspar type and abundance of quartz: Bt-Qz gneiss, Cpx gneiss, Opx gneiss, Cpx-PI

257 gneiss and Cpx-Kf gneiss.

258 Biotite-quartz gneiss was mapped at Ringwood and Wanaque. Alternating biotite-

259 rich and quartzofeldspathic layers define foliation in this rock which typically contains

260 the mineral assemblage Mag-Bt-Kfs-PI-Qtz \pm Grt. Plagioclase comprises $20-65 \%$ of the

261 rock and varies inversely with quartz which locally accounts for up to $75 \%$. Microcline

262 constitutes $10-15 \%$ of this unit. Rusty brown garnets, up to $3 \mathrm{~mm}$ in diametre, are locally

263 abundant (<20\%). Apatite, clinopyroxene, and rutile are common accessories. Bt-Qz

264 gneiss has REE abundances similar to average upper crust, as represented by post-

265 Archean Australian shale (PAAS) (McLennan 1989)(Fig. 6). Garnet-bearing samples

266 show heavy rare earth element (HREE) enrichment, and quartz-rich samples are

267 depleted in all REE, a dilution effect of quartz (McLennan 1989). Most samples plot as

268 wacke on the discrimination diagram of Garrels and McKenzie (1971) (Fig. 5). REE and

269 major element abundances suggest that Bt-Qz gneiss is an immature clastic

270 metasedimentary rock.

271 Quartz-poor rocks that are rich in clinopyroxene and/or orthopyroxene were

272 mapped as Cpx and Opx gneiss, respectively, at the Ringwood deposit. Cpx gneiss is

273 composed of green, monomineralic, cm-scale bands of Fe-rich diopside and a cream-

274 colored rock whose approximate mineral composition is dominated by plagioclase

$275(\sim 60 \%)$, and clinopyroxene $(\sim 30 \%)$, along with titanite and trace quartz and apatite. Opx

276 gneiss stratigraphically underlies the Cpx gneiss. Opx gneiss has alternating light-

277 colored Opx-rich layers and dark-colored Hbl-rich layers. The combined mineral 
278 assemblage is Bt-Kfs-Cpx-Mag-Opx-Hbl-PI with accessory apatite. Magnetite is 279 particularly abundant in Opx-rich layers, comprising up to $\sim 15 \%$ of these layers. Both 280 the Cpx gneiss and Opx gneiss most resemble the garnet-bearing samples of Bt-Qtz 281 gneiss with respect to REE abundances, displaying gullwing-shaped curves with more 282 or less pronounced negative Eu anomalies (Fig. 6), suggesting a predominantly clastic 283 composition of the protoliths (Fig. 6), but with Fe-enrichment.

284 Clinopyroxene-plagioclase gneiss, mapped at Wanaque, is pale gray to pale 285 pink on both fresh and weathered surfaces. It has a distinct lineation defined by grayish286 green clinopyroxene. Locally lenses of coarser-grained clinopyroxene or magnetite 287 define a discontinuous foliation. Cpx-PI gneiss has the mineral assemblage Ap-Ttn-Cpx$288 \mathrm{PI}$ and may contain quartz, K-feldspar, orthopyroxene, magnetite, perthite and/or 289 antiperthite. Pyroxenes comprise $\sim 20 \%$ of the rock.

290 Cpx-PI gneiss has moderately enriched, gently sloping REE curves with 291 abundances between those of PAAS and carbonates (Fig. 6), suggesting a mix of 292 clastic and calcareous input in the protolith. The lack of a Eu anomaly in the Cpx-PI 293 gneiss may be explained by the high modal abundance of plagioclase, as well as the 294 contribution of carbonate. Cpx-PI gneiss plots as wacke on the discrimination diagram 295 of Garrels and McKenzie (1971) (Fig. 5).

296 Clinopyroxene-K-feldspar gneiss was mapped at Warwick. Cpx-Kf gneiss has 297 two variants, a well-foliated rock with alternating layers rich in either $\mathrm{Cpx}$ or $\mathrm{Kf}$ in the 298 western part of the map and a massive, mafic-poor rock in the eastern part. Both units 299 are quartz-poor. In the foliated western unit, felsic layers are dominantly microcline, 300 which constitutes up to $90 \%$ of the layers. Mafic layers are dominantly Cpx, which 
301 constitutes up to $\sim 80 \%$ of the layers. In the massive eastern unit, perthite and microcline 302 make up $\sim 80 \%$ of the rock with quartz contributing $15 \%$. Mg, Ap, and Ttn are minor 303 components of both variants of Cpx-Kf gneiss. Plagioclase is generally absent from 304 Cpx-Kf gneiss, except where it grades into amphibolite. Petrographically, the Cpx in the 305 western unit is dark green and pleochroic. It is iron-rich, with molar ratios of $\mathrm{FeO} /(\mathrm{FeO}+$ $306 \mathrm{MgO})$ between 0.80 and 0.93 .

A thin band of Mc- and perthite-bearing amphibolite separates the two types of 308 Cpx-Kf gneiss. This amphibolite shows several geochemical affinities with the Cpx-Kf 309 gneiss. Both rocks are enriched in REE, with fairly smooth, steeply sloping curves 310 produced by La/Lu ratios of $\sim 39$, (Fig. 6). This pattern resembles that of alkaline,

311 continental rift volcanic rocks (Winter 2001). However Smith (1990) found ultra-potassic

312 basaltic rocks with similar REE abundances in the Central Metasedimentary Belt. The

313 Cpx-Kf gneiss and the neighboring amphibolite define a calc-alkaline trend on the AFM 314 diagram (Fig. 7). The Mc-bearing amphibolite plots in the field of basalt and the Cpx-Kf 315 gneiss plots from rhyolite to trachy-andesite on the $\mathrm{Zr} / \mathrm{Ti}$ vs. $\mathrm{Nb} / \mathrm{Y}$ modified diagram of 316 Winchester and Floyd, (Pearce, 1996) (Fig. 8). Both rocks plot in the metaigneous field 317 on the $\mathrm{Zr} / \mathrm{TiO}_{2}$ vs. Ni discrimination diagram of Winchester and Floyd (1984) (not 318 shown). Taken together, these geochemical characteristics suggest that both rocks 319 originated as members of a bimodal volcanic suite.

320 Amphibolites

321 Amphibolites are spatially associated with $\mathrm{Fe}$ deposits at all three areas.

322 Amphibolite is dark gray, or black and white on fresh and weathered surfaces. It is 323 medium-grained, and usually displays mineral lineations defined by $\mathrm{Hbl} \pm$ Mag. Locally, 
324 1-2 mm thick segregations of light- and dark-colored layers create a discontinuous

325 foliation. The characteristic mineral assemblage is $\mathrm{Hbl}-\mathrm{Pl} \pm \mathrm{Cpx} \pm \mathrm{Opx} \pm \mathrm{Mag} \pm \mathrm{Bt}$.

326 Plagioclase is the most abundant mineral, comprising $50-75 \%$ of the rock. Hornblende

327 comprises $20-50 \%$ of the rock, and varies inversely with clinopyroxene and/or

328 orthopyroxene which together constitute $10-30 \%$ of the rock. Magnetite is a common

329 accessory to minor mineral. Apatite, titanite, and microcline are accessory to minor

330 minerals in Warwick amphibolite.

331 Most amphibolites from the Wanaque and Ringwood map areas have gently

332 sloping REE curves with La/Lu ranging from 1.5 to 2.7 , some with small negative Eu

333 anomalies (Fig. 6). These REE patterns resemble those of basalts from the Scotia

334 Sea, a modern back-arc basin (Fretzdorff et al. 2002). The most enriched samples

335 have REE abundances similar to basaltic sills and dykes from the western edge of the

336 Elzevir Terrane in the Central Metasedimentary Belt (CMB), identified as a back-arc

337 basin, which opened during the Elzeverian orogeny (Smith and Holm 1990; Dickin

338 2010). The massive amphibolite that occurs as a tens of metres-scale inclusion in the

339 basement tonalitic gneiss at Ringwood has a distinctly higher LREE/HREE ratio than

340 other amphibolites at Ringwood and Wanaque (Fig. 6). The LREE/HREE ratio of this

341 unit suggests that these mafic dykes are associated with basin volcanics, rather than

342 basement magmatism which yields lower La/Yb ratios (Volkert 1999).

343 Most amphibolites form a cluster centred on the field of back-arc basin basalt on

344 the tectonic discrimination diagram of Cabanis and Lecolle (1989). The LREE-enriched

345 amphibolite from the basement at Ringwood has a distinct position in the calc-alkali 
346 field, and Kfs-bearing amphibolites from Warwick cluster in the high-La region of the

347 calc-alkali field (Fig. 9).

349 High-Fe Units and Fe-Alteration

350 Ore in each of the studied localities has been extracted, and available ore 351 samples were limited to waste piles associated with past mining activity. Accordingly,

352 ore characteristics were not examined systematically in this study.

353 Stratiform rock units composed of massive clinopyroxene are spatially associated

354 with ore in all three map areas. Massive Cpx rocks are herein referred to as diopsidite,

355 in keeping with local convention. Diopsidite occurs as a monomineralic rock, or as a

356 component of quartz-diopside gneiss, a unit composed of alternating centimetre- to

357 metre-scale layers of light-gray quartz and dark green diopside. Cpx in these rocks

358 generally has $\mathrm{FeO} /(\mathrm{FeO}+\mathrm{MgO})$ values between 0.4 and 0.6 . Qtz-Di gneiss occurs at

359 Wanaque and Warwick and is spatially associated with ore. Contacts between layers

360 are very sharp. Diopside layers may contain up to $2 \%$ apatite, either as inclusions or

361 interstitial grains. Minor magnetite is disseminated in both layers. Massive diopsidite,

362 Qtz-Di gneiss and ore are enriched in iron and nearly aluminum-free, characteristics

363 shared with modern metalliferous sediments (Spry et al. 2000)(Fig. 10).

364 At Wanaque, Qtz-Di gneiss includes light-brown weathering, sugary-textured,

365 massive feldspathic layers up to $15 \mathrm{~cm}$ thick. Feldspathic layers have the assemblage

366 Ttn-Cpx-Kfs-Pl \pm Qtz $\pm A p \pm$ Mag. Their REE abundances are similar to those of $\mathrm{Cpx}-\mathrm{Kf}$

367 gneiss (Fig. 6), except that they are more enriched in MREE and HREE. Given this

368 similarity, the generally massive appearance of the feldspathic layers, and their sharp 
369 boundaries with quartz and diopside layers, the feldspathic layers are interpreted to 370 have formed from a tuffaceous protolith.

371 Amphibolite is sometimes altered in proximity to ore deposits or exploration pits.

372 At Wanaque, scapolite and biotite may comprise significant percentages of the whole

373 rock. Scapolite occurs with or without plagioclase and ranges from $15-75 \%$ of total

374 mineral abundance. Where scapolite-bearing amphibolite is in contact with late 375 leucogranite, plagioclase has replaced scapolite, an indication of contact 376 metamorphism, and a pre-intrusion age of alteration. Biotite may comprise as much as $37725 \%$ of altered amphibolites at Wanaque. In contrast, biotite-bearing amphibolites at 378 Ringwood are rather widespread, and show equilibrium textures.

A texturally distinctive amphibolite occurs at Ringwood in close spatial 380 association with ore (Fig. 11). This rock is characterized by its anastomosing bands of 381 hornblende, which create a striped or spotted appearance depending on the surface 382 exposed. This rock occurs within the tonalitic gneiss as elongate pods that are 383 concordant with the foliation. The REE composition of this unit is similar to amphibolites 384 of metabasaltic origin (Fig. 6). However, the hornblende in the anastomosing bands of 385 this amphibolite is enriched in $\mathrm{Fe}$ and $\mathrm{Cl}$, compared to hornblendes from other 386 amphibolite pods within the tonalitic gneiss at the same map area (Fig. 12), consistent 387 with alteration by an iron-rich brine. Based on texture and composition, this amphibolite 388 is interpreted have formed from the metamorphism of tectonically dismembered mafic 389 dykes that had undergone stockwork fracturing and associated alteration.

391 Leucogranite 
This ridge-forming rock is pale salmon and white on fresh surfaces, and weathers

393 to light-grey or beige. It is coarse-grained and mafic minerals are generally absent.

394 Most examples of this rock are massive, but elongate quartz grains define a poorly

395 developed lineation and foliation in some outcrops. Quartz and K-feldspar are dominant;

396 plagioclase is a minor constituent. Leucogranite cross-cuts all stratified units and

397 overprints ore-associated alteration, and so must post-date magnetite mineralization.

399 Discussion

$400 \quad$ Tectonic Setting

$401 \quad$ The mapped areas lie within an ancient back-arc basin (Volkert and Drake 1999;

402 Volkert 2004; Volkert and Aleinikoff 2007; Peck 2009; Volkert et al. 2010). The mapped

403 field areas have the following lithological and geochemical characteristics supportive of

404 a back-arc basin tectonic setting: 1) metabasalts exhibit REE enrichments common to

405 modern back-arc basin basalts, and plot on or near the field of back-arc basin basalts

406 on the tectonic discrimination diagram of Cabanis and Lecolle (1989); 2) clastic

407 metasedimentary rocks are immature, with most plotting in the field of greywacke on

408 the diagram of Garrels and McKenzie (1971); 3) felsic metavolcanic rocks have extreme

409 enrichments in LREE, typical of continental rifts and ensialic back-arc environments

410 (Smith and Holm 1990); 4) some metabasalts and felsic metavolcanic rocks show

411 subduction zone influence on mantle normalized trace element plots (not shown) (Sun

412 and McDonough 1989) including enrichments in large ion lithophile elements (Rb, $\mathrm{Ba}$,

413 and $\mathrm{K}$ ), depletions in high field strength elements ( $\mathrm{Th}, \mathrm{Zr}$, and $\mathrm{Ti}$ ) and strong negative

414 anomalies in $\mathrm{Nb}$ and $\mathrm{Ta} ; 5)$ stratiform ore bodies and associated altered rocks have 
415 mineralogical and geochemical characteristics consistent with genesis from a seafloor

416 hydrothermal system. Hydrothermal systems are common in back-arc basins (Gamo et 417 al. 2006; Yang and Scott 2006).

418 Back-arc settings have been established for the Central Metasedimentary Belt 419 (Smith and Holm 1990; Dickin and McNutt 2007) and for most of the Adirondacks 420 (Chiarenzelli et al. 2015). The Central Metasedimentary Belt is interpreted as the

421 northernmost extension of an aulacogen over $400 \mathrm{~km}$ long (Dickin et al. 2016). The 422 Trans-Adirondack back-arc basin is considered a roughly contemporary, but smaller 423 extensional structure which opened $\sim 50 \mathrm{~km}$ to the east (Chiarenzelli et al. 2015). Given 424 the regional scale of back-arc extension, it is likely that the New Jersey Highlands is a 425 more southerly, en echelon expression of the same, pre-Shawinigan episode 426 (Chiarenzelli et al. 2015).

428 Origin of Stratiform Deposits

429 At Wanaque and Warwick, the bi-mineralic quartz-diopside (Qtz-Di) gneiss lies in 430 close proximity to magnetite ore, and is concordant with the stratiform trend of the 431 deposits. The Qtz-Di gneiss consists of alternating cm-scale layers of quartz and 432 diopside. At Wanaque, layer thickness increases to meter scale with increasing 433 proximity to the Roomy mine. Layers are continuous over metres, and contacts between 434 layers are sharp and non-gradational. No other unit in the study areas displays such 435 distinct layering, and so this texture is consistent with primary layering rather than 436 metamorphic segregation. 
Massive diopsidite is spatially associated with magnetite ore at all three study

438 localities. $\mathrm{Al}_{2} \mathrm{O}_{3}$ is less than $1 \%$ by weight in diopsidite and Qtz-Di gneiss, and $\mathrm{Fe}_{2} \mathrm{O}_{3}$

439 ranges from $8.7-13.8 \%$. It is implausible that the Di-rich units formed as a result of

440 replacement or metasomatic processes affecting siliciclastic or volcanic strata due to

441 the near absence of aluminum in these rocks, and the lack of alteration haloes or

442 gradational contacts with adjacent units. Qtz-Di gneiss, diopsidite and ore all are more

443 similar chemically to modern metalliferous sediment than to neighboring

444 metasedimentary units (Fig. 10). Therefore, these units are interpreted to have formed

445 as chemical sediments.

446 The best analogue for these rocks is iron formation (IF). IF is defined as "a

447 chemical sediment, typically thin bedded or laminated, whose principal chemical

448 characteristic is an anomalously high content of iron, commonly but not necessarily

449 containing layers of chert," (Klein 2005). The quartz-diopside gneiss and spatially

450 related magnetite are consistent with the definition of IF, and the existing diopside-

451 dominated assemblages are compositionally and mineralogically consistent with

452 carbonate-facies IF metamorphosed under granulite conditions:

$$
\text { Chert }+ \text { Ankerite }=\text { Clinopyroxene }+ \text { Carbon Dioxide }
$$$$
2 \mathrm{SiO}_{2}+\mathrm{Ca}(\mathrm{Fe}, \mathrm{Mg})\left(\mathrm{CO}_{3}\right)_{2}=\mathrm{Ca}(\mathrm{Fe}, \mathrm{Mg}) \mathrm{Si}_{2} \mathrm{O}_{6}+2 \mathrm{CO}_{2} \text {. }
$$

Variation between diopsidite and quartz-diopside gneiss can be attributed to

456 variation in the ratio of ankerite to chert in the protolith, with chert-rich protoliths

457 corresponding to Qtz-Di gneiss. Adjacent magnetite and diopside-rich layers can be

458 attributed to shifts between oxide-facies and cherty carbonate-facies IF deposition. 
A seafloor exhalative source for iron is supported by the spatial association of 460 amphibolite (metabasalt) and ore at all three localities. Magma chambers beneath the 461 seafloor would drive hydrothermal circulation to and from the surface. The 462 amphibolites, even those considered herein to be altered, plot within or just outside the 463 range of normal composition for andesite and basalt on the alteration box plot of Large 464 (2001) (not shown), indicating that alteration was spatially limited and controlled by 465 proximity to a hydrothermal vent or subsurface conduit.

466 Felsic metavolcanic rocks at Warwick, as well as the feldspathic interlayer of the 467 Qz-Di gneiss at Wanaque, plot within the range of normal composition for dacite on the 468 Large (2001) alteration box plot, except for one sample which indicates slight sericitic 469 alteration. Taken together, these data for mafic and felsic metavolcanic rocks show that 470 the major-element-based discrimination diagrams referred to herein are appropriate.

\section{Origin of Basement-Hosted Ore and Alteration}

Several magnetite showings in the Ringwood map area occur within structurally-

474 concordant, basement-hosted amphibolite pods. These pods are interpreted as a 475 tectonically dismembered mafic dyke, based on their small size, boudin-like form, 476 geochemical composition, and presence within a metaintrusive rock. In each case the 477 mineralization is associated with a distinct anastomosing fabric defined by $\mathrm{Fe}-\mathrm{Cl}$-rich 478 amphibole. The distinct texture of these amphibolites is consistent with their having 479 resulted from the compressional deformation of a stockwork vein system, as has been 480 demonstrated in other metamorphosed ore deposits (e.g. Johnston, 1996)). 481 Furthermore, the $\mathrm{Fe}-\mathrm{Cl}-$ rich composition of these deformed fractures indicates that they 
482 were altered by a Fe-rich brine. The altered amphibolites, and the ore that they host,

483 immediately underlie a wedge of stratabound diopsidite at the base of the supracrustal

484 sequence. The diopsidite grades into Opx gneiss along strike (Fig. 4).

485 The field relationships described above suggest that all three Fe-rich rock units

486 (basement-hosted ore, diopsidite, Opx-gneiss) are related. This is consistent with

487 spatial relationships that have been documented in exhalative deposits, where a

488 fracture-associated feeder zone underlies stratiform ores that exhibit facies transitions

489 along strike (e.g., Sullivan and Annaraq in (Leach, D.L. et al. 2005); Jason in (Gardner 490 and Hutcheon 1985).

491 In the case of the Ringwood ores, rift-related faults may have served as conduits

492 for both mafic magmas and hydrothermal fluids. The Fe-rich brines altered host rock

493 along the flow path, formed a mineralized stockwork system beneath the seafloor, and

494 vented into seawater where stratiform IF formed through precipitation and deposition.

495 Carbonate-facies IF strata accumulated proximal to the vent, and was subsequently 496 metamorphosed to diopsidite. More distally, less abundant Fe-rich precipitates 497 contributed to immature clastic sediments, which were metamorphosed to form Opx498 gneiss (Fig. 13).

499

500 Conclusions

$501 \quad$ Magnetite ore from our study sites is interpreted as metamorphosed iron 502 formation. Sharp contacts between ore and diopsidite or Qz-Di gneiss represent 503 changes between oxide and cherty carbonate facies IF. Spatially associated volcanic 504 strata, including both metabasalts and felsic alkaline metavolcanic rocks, are evidence 
505 for localized heat sources to drive the hydrothermal transport of iron. Distinctively 506 textured, Fe-enriched amphibolite at Ringwood is evidence for a hydrothermal vent that

507 created small, vent-proximal deposits of massive magnetite and Fe-enrichment in the 508 vent-distal sediments.

509 The syngenetic, sedimentary exhalative model for carbonate-hosted zinc and 510 iron deposits in the western New Jersey Highlands (Johnson and Skinner 2003; Peck 511 2009) is here extended to a larger variety of host rocks, including the regional 512 basement. Given the variety of siliciclastic, volcaniclastic, and chemical sediments 513 common to back-arc basins, it is not surprising to find syngenetic deposits from such 514 settings in a variety of hosts. The associated rock units and ore facies would be 515 dependent upon the location of the vent, distance from the vent, and intrabasinal 516 circulation capable of distributing ore-bearing fluids to vent-distal and vent-proximal 517 positions (Leach et al. 2005). The sedimentary exhalative model is appealing for its 518 simplicity. It avoids the need to invoke an assortment of genetic processes based on 519 host lithologies (Puffer 2001), and explains the consistency of ore-body mineralogy 520 (primarily massive magnetite) as a characteristic of intrabasinal hydrothermal fluid 521 chemistry and seawater oxidation state. 


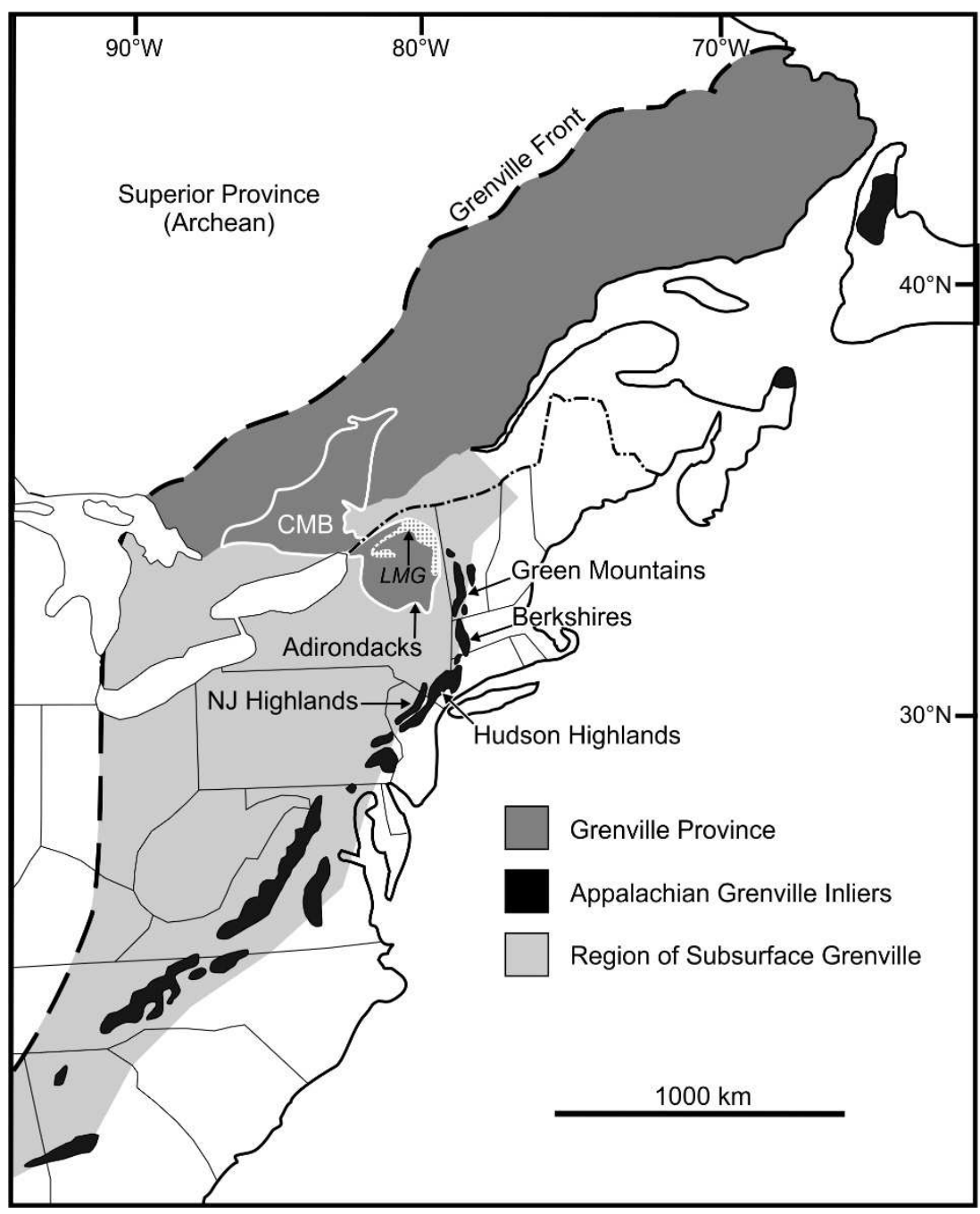

Figure 1. Grenville Province of Eastern North America (Modified from Tollo et al. 2010). CMBCentral Metasedimentary Belt; LMG-Lyon Mountain Granite. 


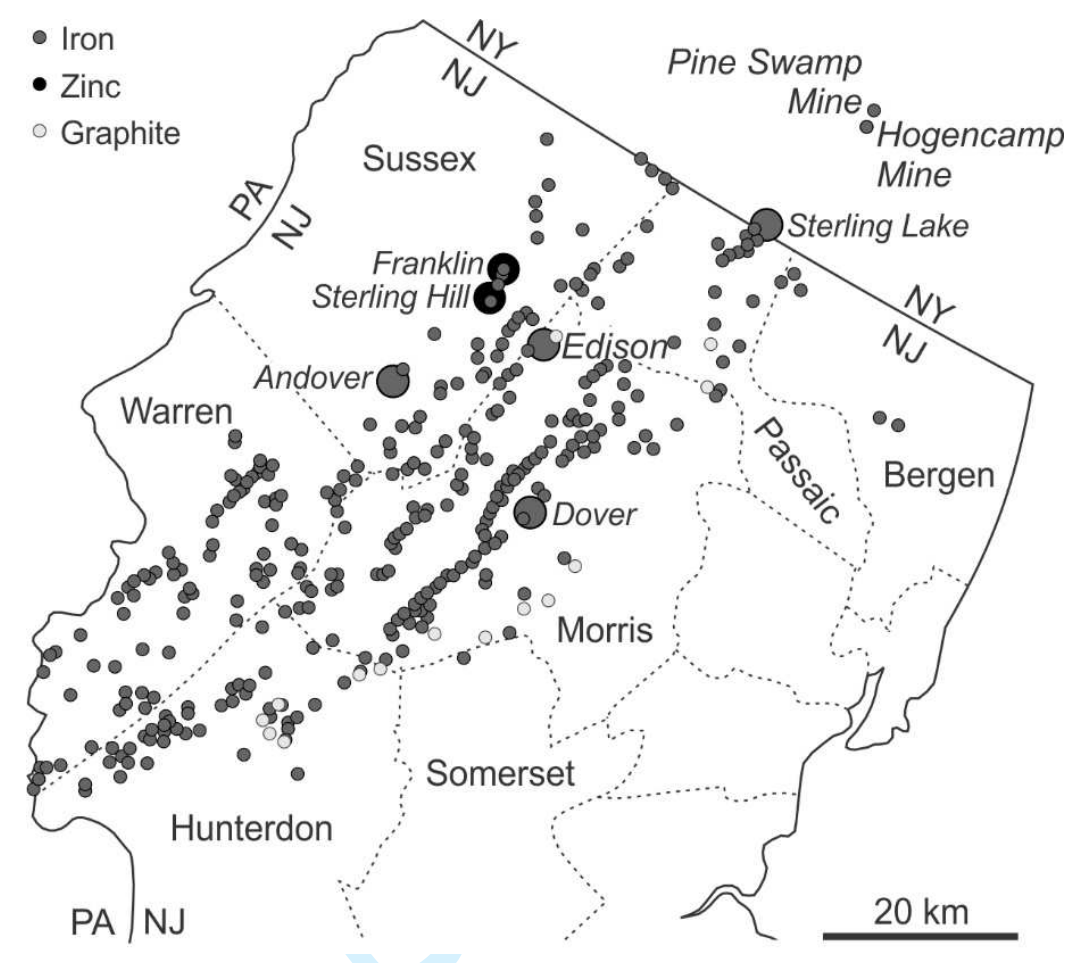

Figure 2: Mines of the New Jersey Highlands, with nearby Pine Swamp and Hogencamp mines 


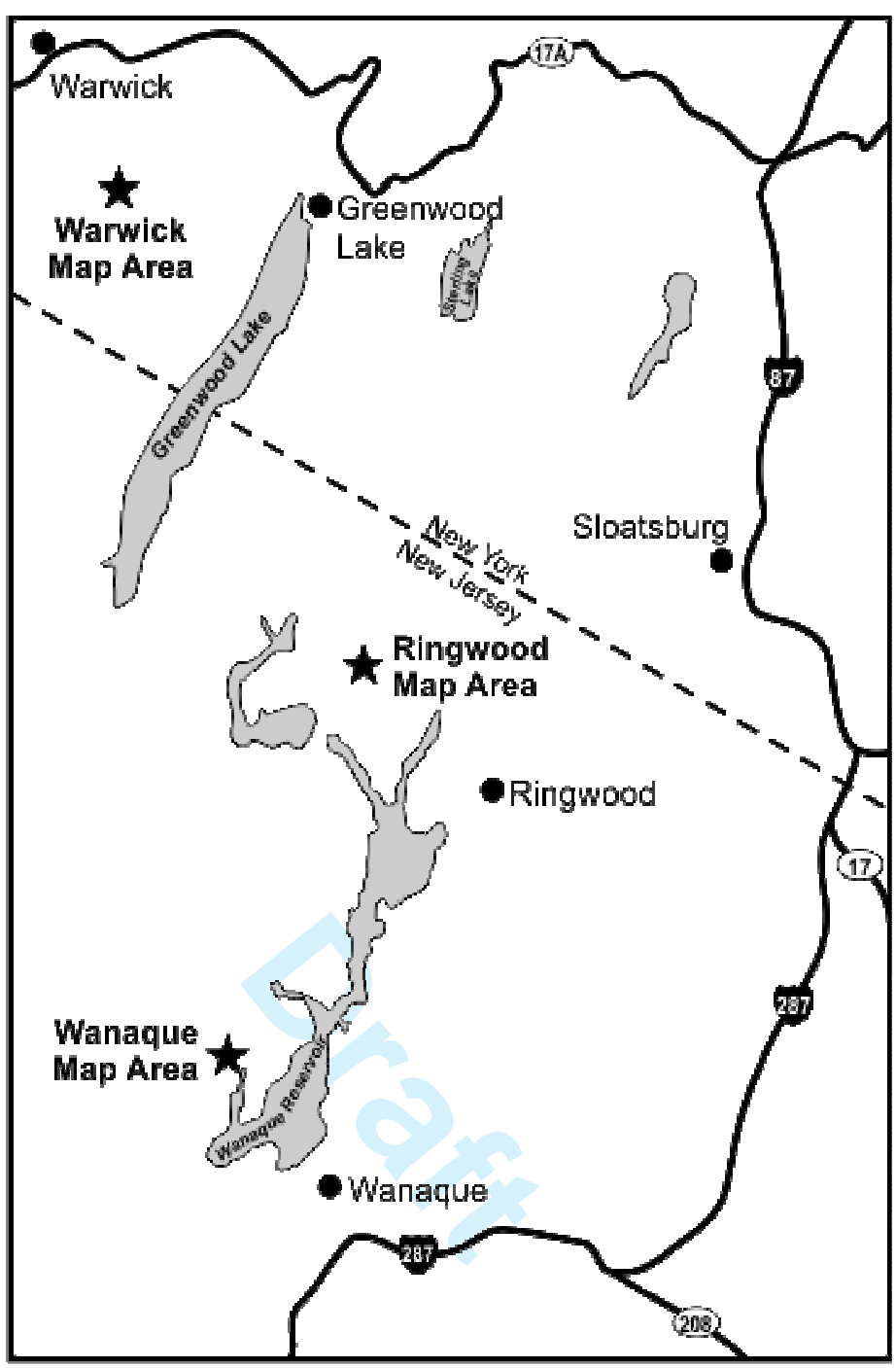

Figure 3: Study Site Location Map 

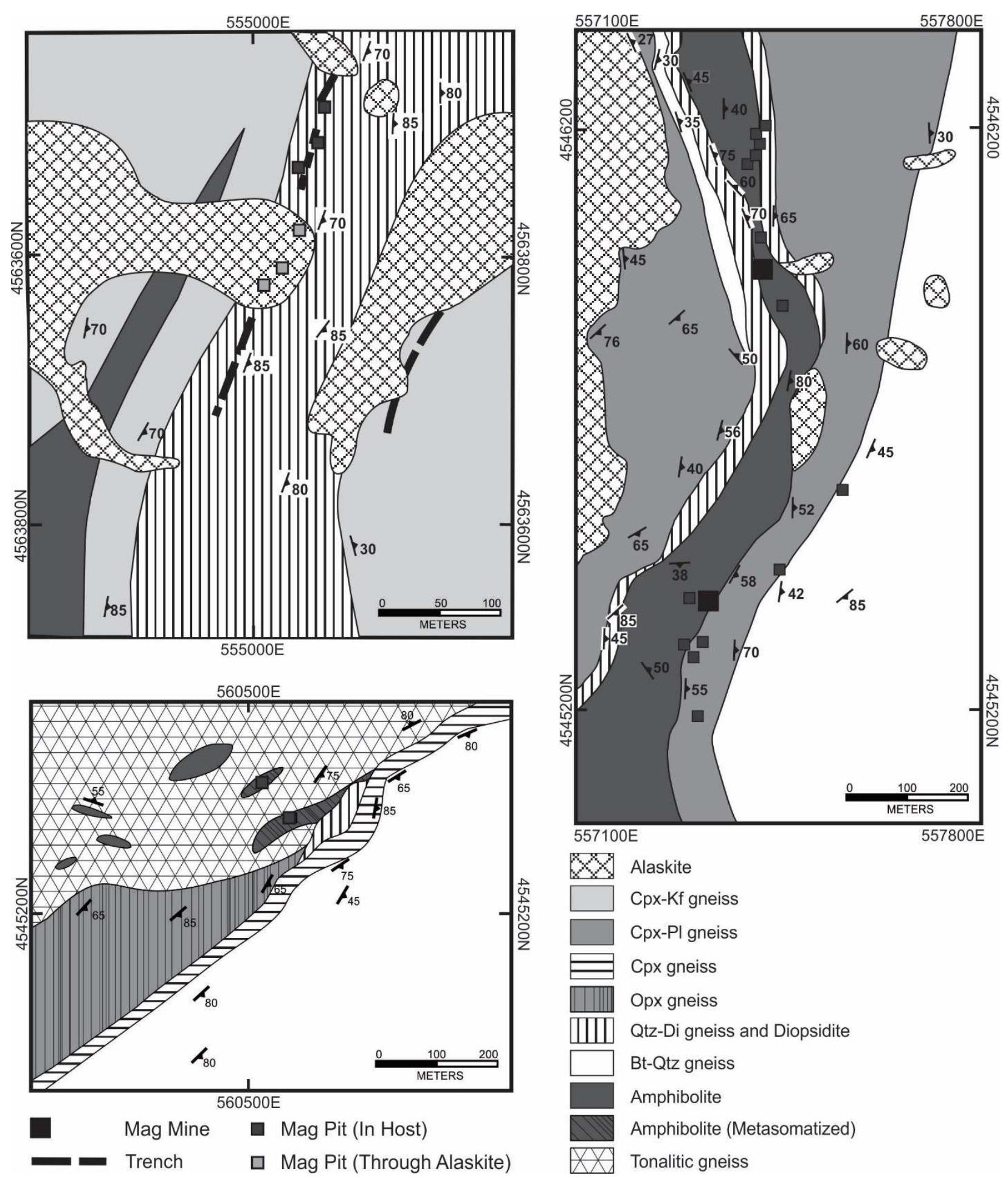

542 Figure 4. Geological maps of the Wanaque (upper left), Warwick (right) and Ringwood (lower left) Areas 


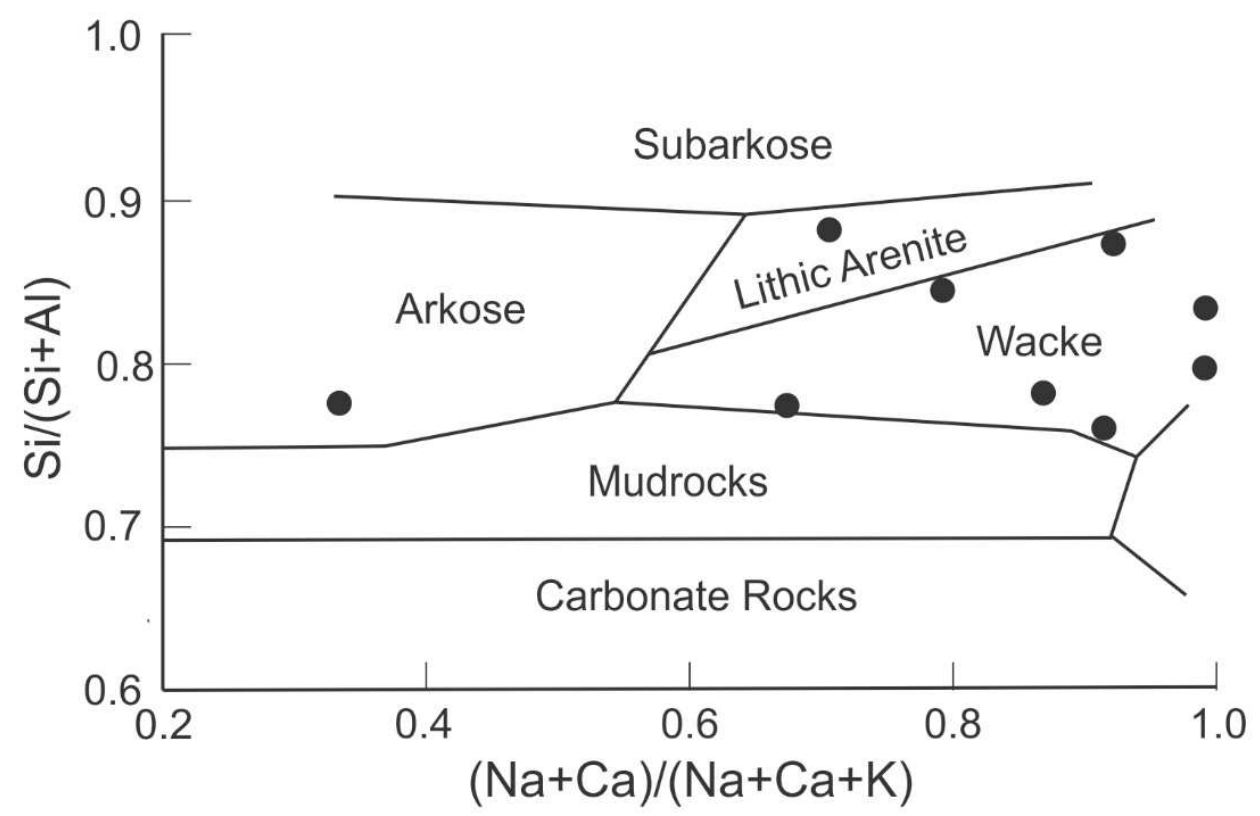

Figure 5: Clastic and mixed calcareous/clastic gneisses, after Garrels and McKenzie (1971) 545 

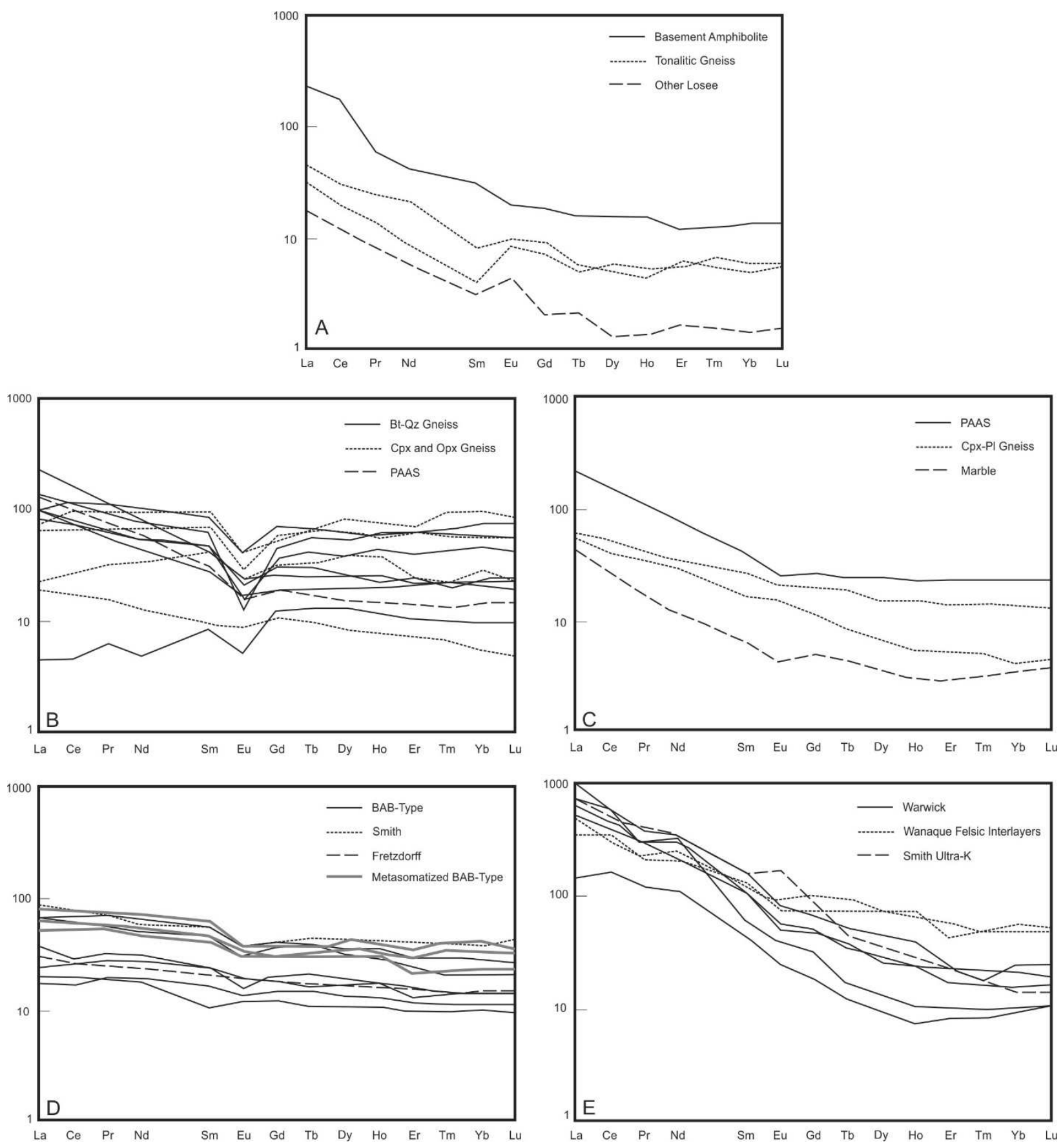

Figure 6: Chondrite Normalized REE Abundances, using the values of Boynton (1984). A.-Tonalitic gneiss and basement amphibolite; B.-Clastic metasedimentary rocks; PAAS is post-Archaean Australian shale. C.-Mixed calcareous-clastic gneisses; D.-Back-arc basin-type amphibolites; Smith is a basalt from the Central Metasedimentary Belt (CMB) (Smith and Holm 1990). Fretzdorff is a basalt from the Scotia

552 Sea(Fretzdorff et al. 2002). E.-Rocks with rifted-arc affinity; Warwick rocks include Cpx-Kfs gneiss and 553 amphibolite. Wanaque rocks are felsic interlayers in Qtz-Di gneiss. Smith Ultra-K is a leucitite from the 554 CMB(Smith and Holm 1990). 


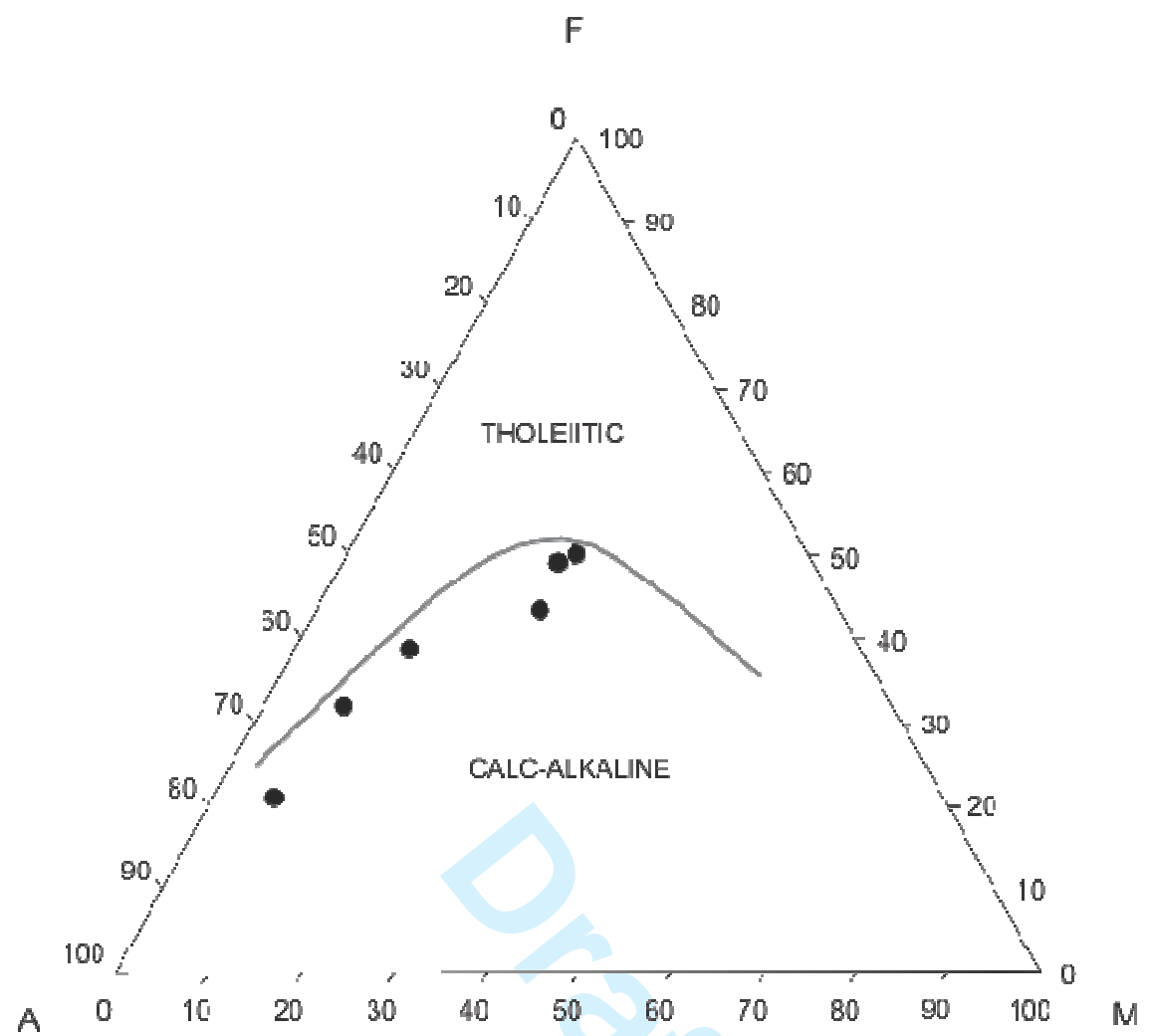

Figure 7: AFM Diagram for Warwick felsic and mafic metavolcanics. Calc-alkaline trend from Irvine and 558

Baragar (1971) 


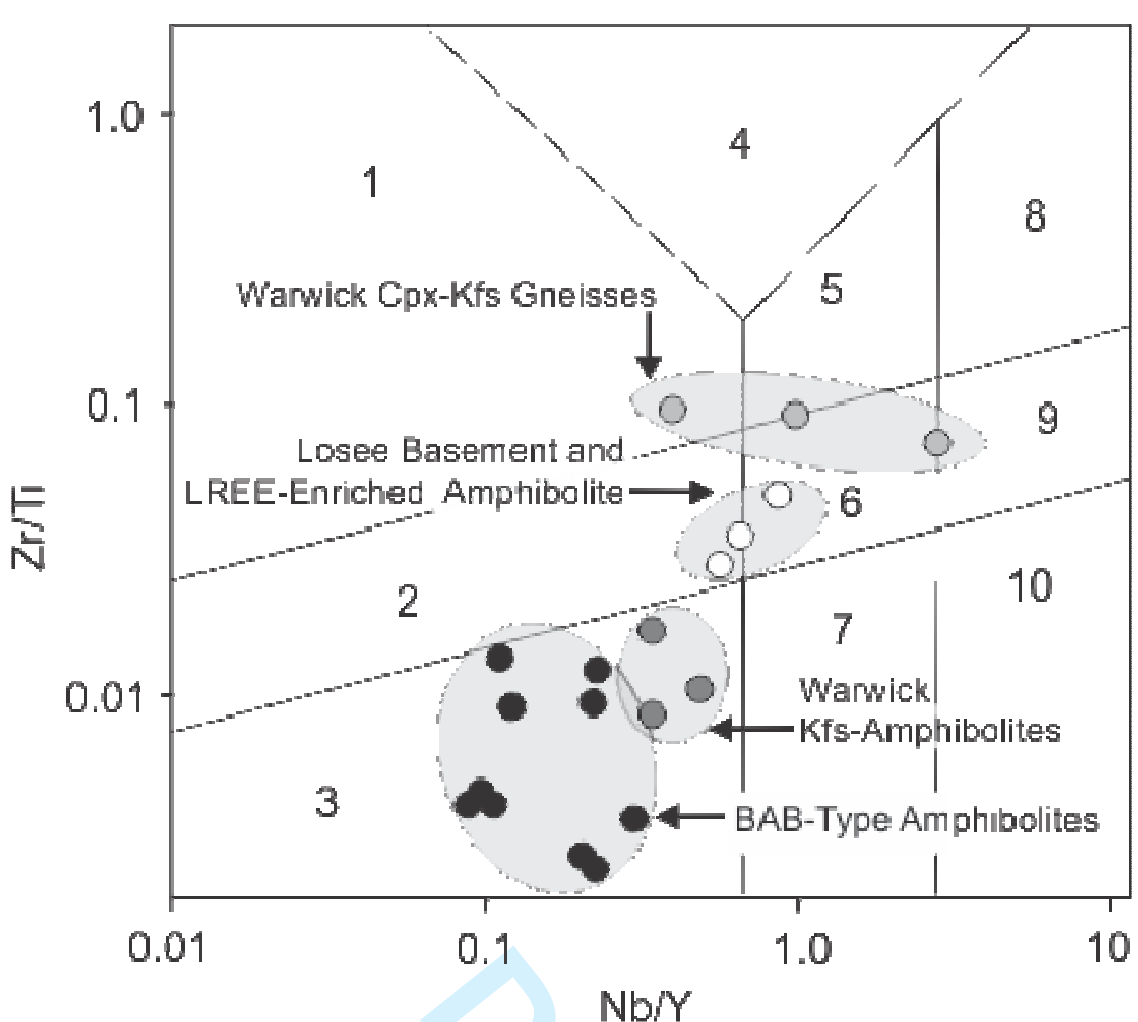

Figure 8: Modified volcanic discrimination diagram of Winchester and Floyd (Pearce, 1996). Fields are: 1rhyolite and dacite; 2-andesite and basaltic andesite; 3-basalt; 4-alkali rhyolite; 5-trachyte; 6-trachyandesite; 7-alkali basalt; 8-phonolite; 9-tephri-phonolite; 10 -foidite 


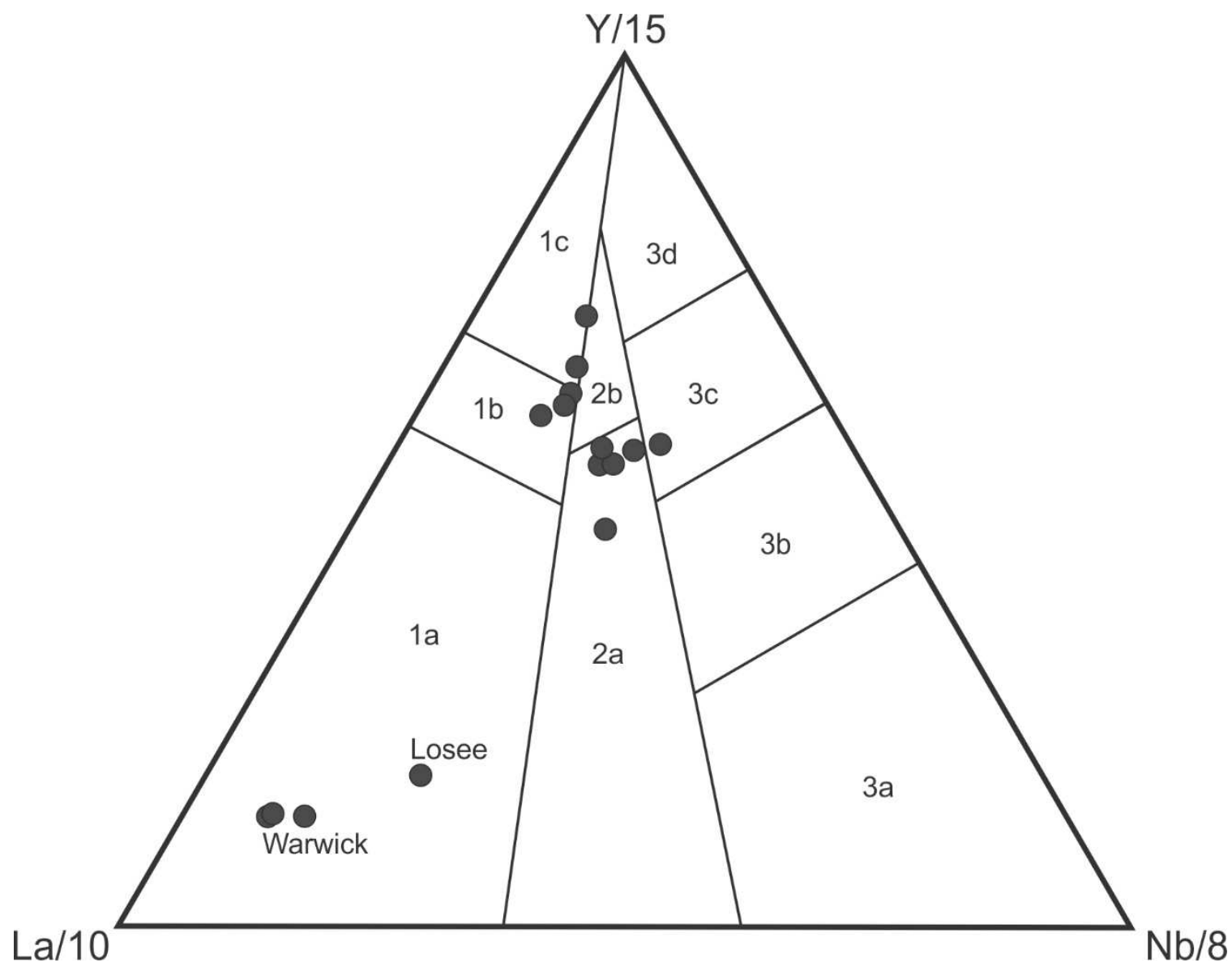

Figure 9: La-Y-Nb Discrimination Diagram of Cabanis and Lecolle (1989). Field symbols: 1 contains volcanic arc basalts. 1a, calc-alkali; 1c, tholeiites; $1 \mathrm{~b}$, overlap between 1a and $1 \mathrm{c}$. 2a, continental basalts; $2 \mathrm{~b}$, back-arc basin basalts (not well defined). 3a, alkali basalts from continental rifts; $3 \mathrm{~b}$ and 3c, E-MORB (3c is weakly enriched); $3 d, N-M O R B$ 


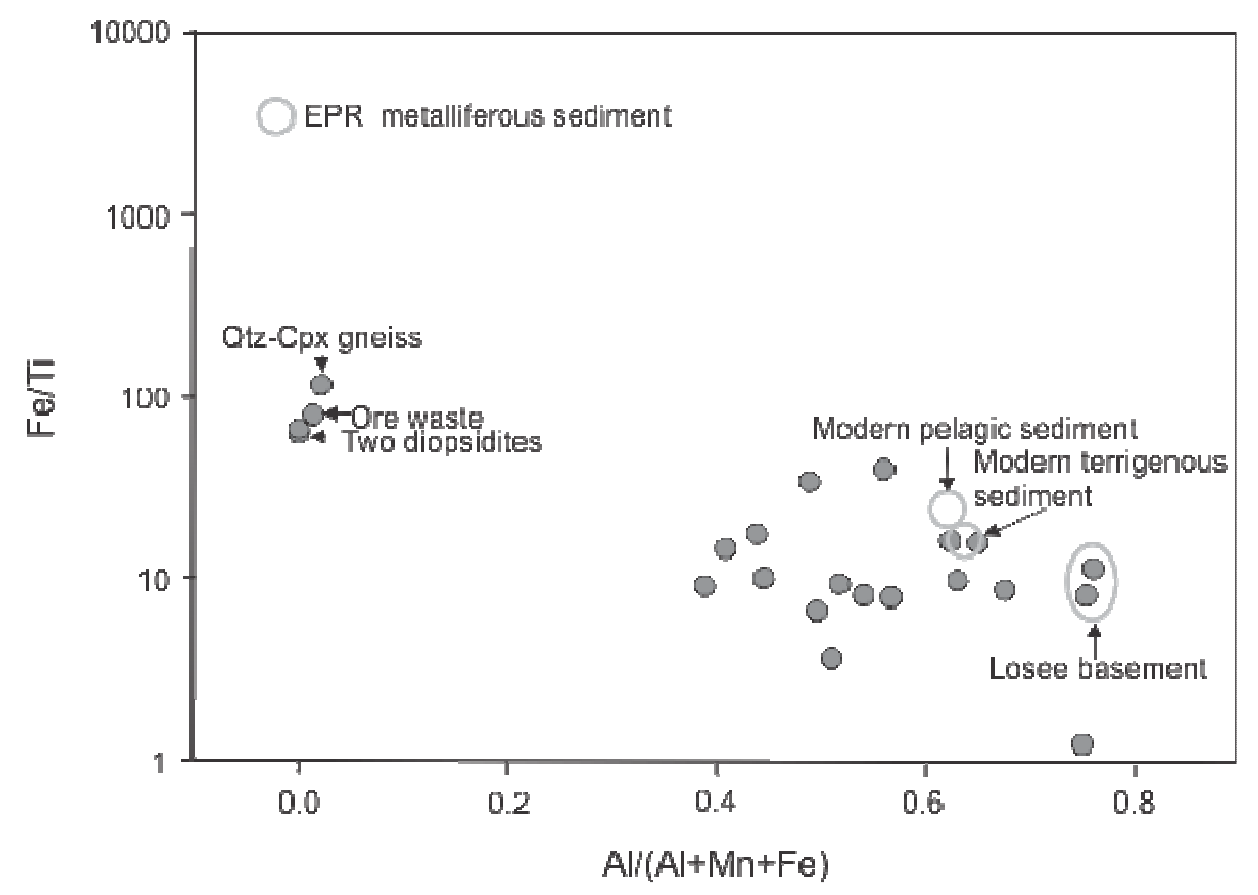

Figure 10: Iron enrichment in metasedimentary rocks and tonalitic gneiss, showing fields for modern metalliferous sediments, terrigenous sediments and pelagic sediments (Peter and Goodfellow 1996). Diagram after Bostrom (1973).
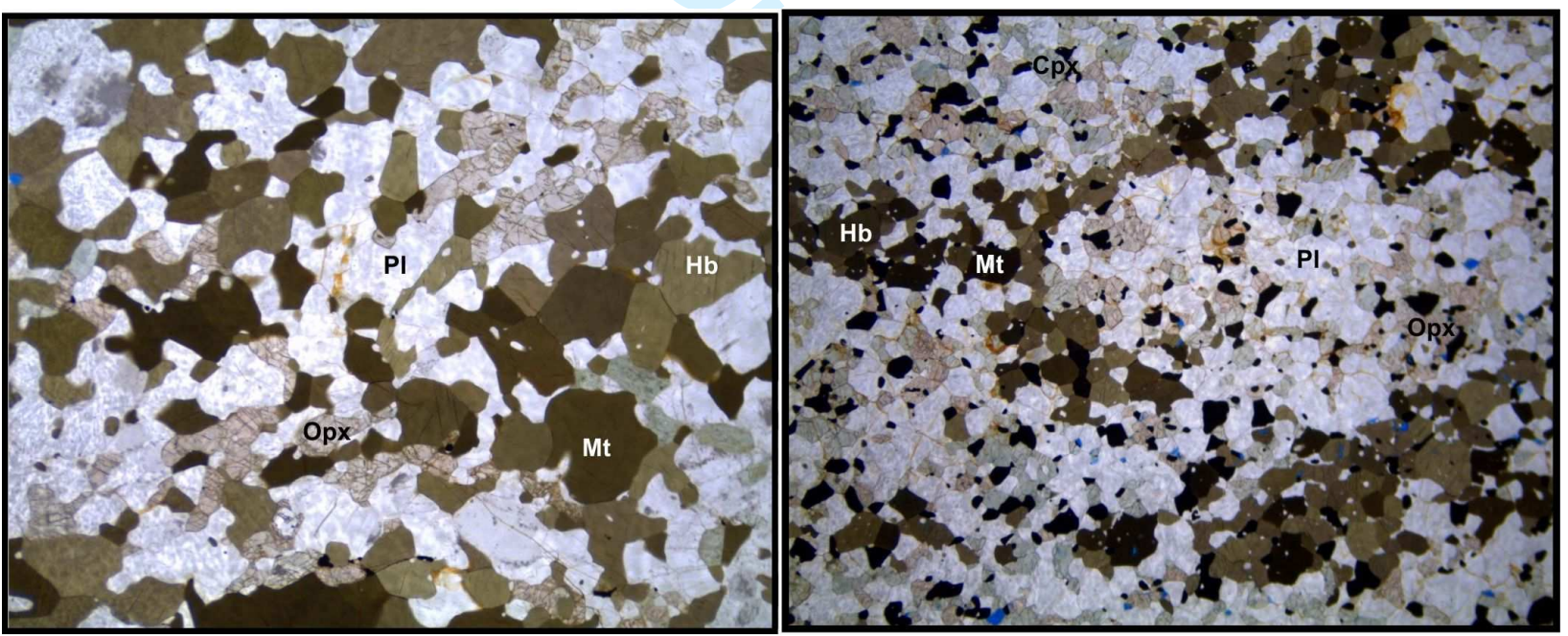

Figure 11: Textural difference between unaltered (left) and altered (right) amphibolites from Ringwood map area. Note anastomosing bands of hornblende in altered rock. Fields of view are $2 \mathrm{~mm}$, left; $5 \mathrm{~mm}$, right. 


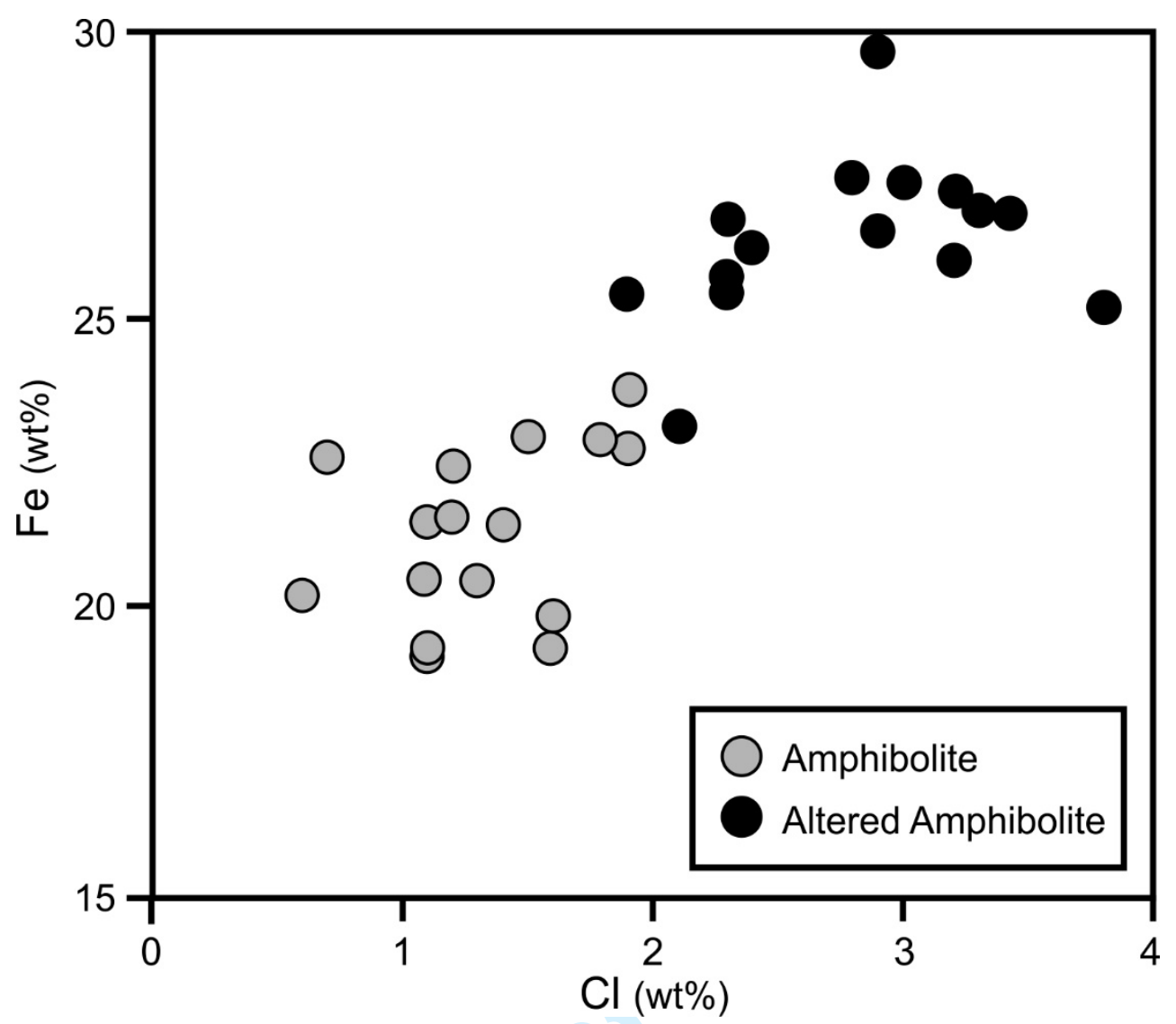

Figure 12: Hornblendes in basement-hosted massive and altered amphibolites at Ringwood. Hornblendes from amphibolites are enriched in $\mathrm{Cl}$ and Fe compared to massive amphibolites. 


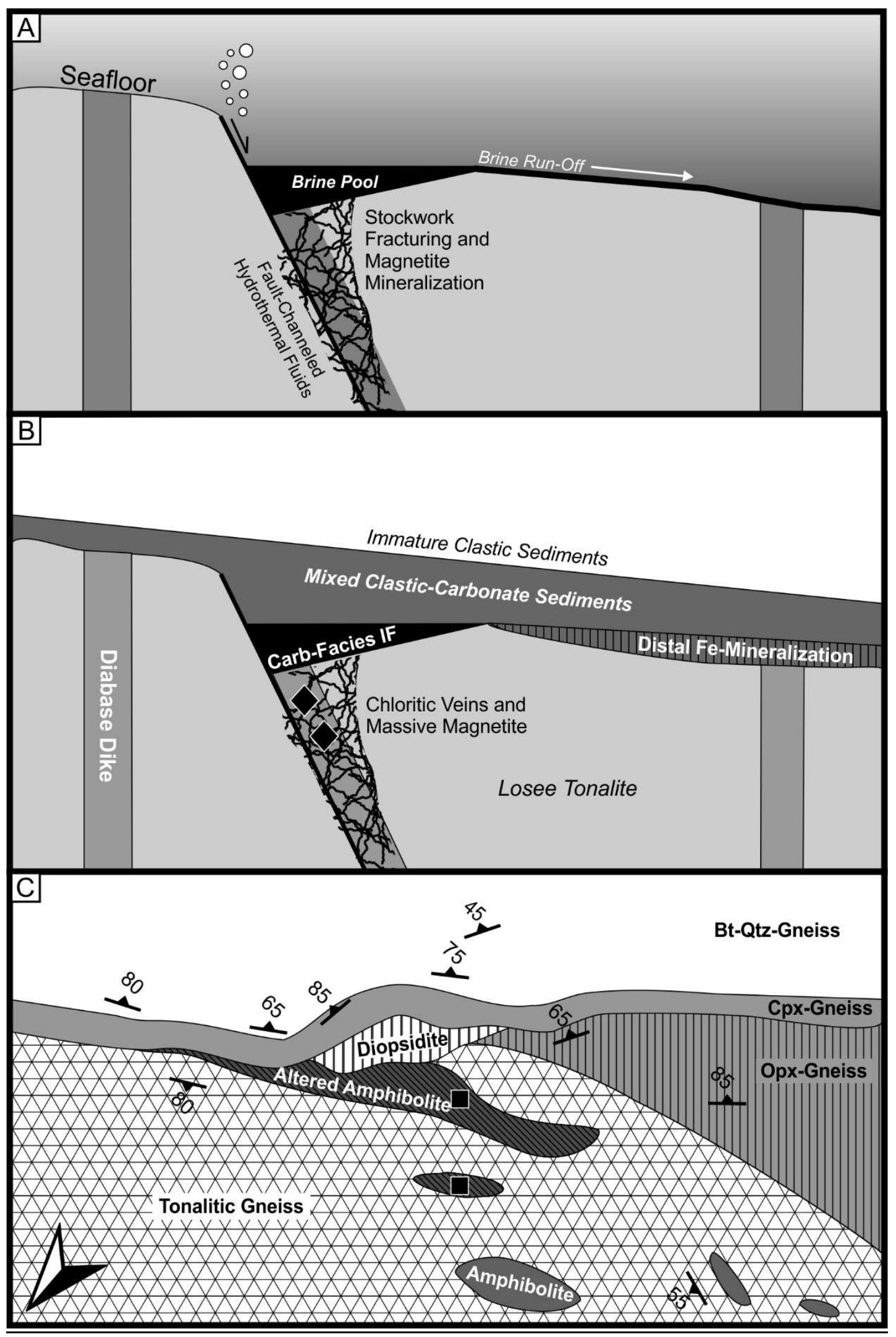


593 Figure 13: Development of massive magnetite in basement amphibolite at Ringwood study area. A)

594 Ascending hydrothermal fluid is channeled through a fault previously exploited by basaltic dike. Fluid

595 fractures the dike, alters its chemistry and vents onto the sea floor as an Fe- and Si-rich brine. Brine

596 collects above the vent and overflows down the paleoslope. B) Sediments fill the basin. Carbonate facies

597 iron formation precipitates from the brine pool. Iron-enriched carbonate and clastic sediments collect

598 above paleoslope. Mixed carbonate and clastic sediments are deposited above the mineralized

599 sediments, followed by dominantly clastic input. C) High-grade metamorphism alters carbonate facies IF

600 to diopsidite, iron enriched clastic and carbonate sedimentary rock to Opx-gneiss, mixed calcareous-

601 clastic sedimentary rock to Cpx-gneiss. Amphibolite dykes are deformed and dismembered. Compare to 602 Fig. 4.

603

604

605

References

606 Boynton, W.V. 1984. Cosmochemistry of the rare earth elements: meteorite studies

607 Rare Earth Element Geochemistry-Developments in Geochemistry 2 (Hendersen, R.,

608 ed.), 63-114.Elsevier Sci. Publ. Co., Amsterdam, Netherlands.

609 Cabanis, B. and Lecolle, M. 1989. Le diagramme La/10-Y/15-Nb/8; un outil pour la

610 discrimination des series volcaniques et la mise en evidence des processus de melange

611 et/ou de contamination crustale. Comptes Rendus de l'Academie des Sciences, Serie

612 2, Mecanique, Physique, Chimie, Sciences de L'Universe, Sciences de la Terre, 309,

$61320 ; 2023-2029$

614 Chiarenzelli, J., Kratzmann, D., and Selleck, B. 2015. Age and provenance of Grenville

615 supergroup rocks, Trans-Adirondack Basin, constrained by detrital zircons. Geology, 43:

616 183-186. 
617 Chiarenzelli, J., Lupulescu, M., Thern, E., and Cousens, B. 2011. Tectonic implications

618 of the discovery of a Shawinigan ophiolite (Pyrites Complex) in the Adirondack

619 Lowlands. Geosphere, 7: 333-356.

620 Dickin, A., Hynes, E., Strong, J., and Wisborg, M. 2016. Testing a back-arc 'aulacogen'

621 model for the Central Metasedimentary Belt of the Grenville Province. Geological

622 Magazine, 153: 681-695.

623 Dickin, A.P. 2010. The extent of juvenile crust in the Grenville Province; Nd isotope

624 evidence. Geological Society of America (GSA) : Boulder, CO, United States, United 625 States.

626 Dickin, A.P., and McNutt, R.H. 2007. The Central Metasedimentary Belt (Grenville

627 Province) as a failed back-arc rift zone; Nd isotope evidence. Earth and Planetary

628 Science Letters, 259: 97-106.

629 Foose, M.P. 1995. Proterozoic low-Ti iron-oxide deposits in New York and New Jersey;

630 relation to Fe-oxide (Cu-U-Au-rare earth element) deposits and tectonic implications.

631 Geology, 23.7: 665-668

632 Fretzdorff, S., Livermore, R.A., Devey, C.W., Leat, P.T., and Stoffers, P. 2002.

633 Petrogenesis of the back-arc East Scotia Ridge, South Atlantic Ocean. Journal of

634 Petrology, 43: 1435-1467.

635 Gamo, T., Ishibashi, J., Tsunogai, U., and Okamura, K. \& Chiba, H. 2006. Unique

636 geochemistry of submarine hydrothermal fluids from arc-back-arc settings of the 
637 western Pacific. In Back Arc Spreading Systems: Geological, Biological, Chemical and

638 Physical Interactions Edited by D.M. Christie, C.R. Fisher and Lee, S. \& Givens, S.

639 American Geophysical Union, Washington, D.C., pp. 147-162.

640 Gardner, H., and Hutcheon, I. 1985. Geochemistry, mineralogy, and geology of the

641 Jason Pb-Zn deposits, Macmillan Pass, Yukon, Canada. Economic Geology, 80: 12576421276.

643 Garrels, R.M., and McKenzie, F.T. 1971. Evolution of Sedimentary Rocks. Norton, New 644 York.

645 Gates, A.E. 1995. Middle Proterozoic dextral strike-slip event in the central

646 Appalachians: Evidence from the Reservoir fault, NJ. Journal of geodynamics, 19: 195647212.

648 Gorring, M.L., Estelle, T.C., and Volkert, R.A. 2004. Geochemistry of the Late

649 Mesoproterozoic Mount Eve granite suite: Implications for Late to post-Ottowan

650 tectonics in the New Jersey-Hudson Highlands. Geological Society of America Memoir:

$651505-523$.

652 Johnson, C.A., Rye, D.M., and Skinner, B.J. 1990. Petrology and stable isotope

653 geochemistry of the metamorphosed zinc-iron-manganese deposit at Sterling Hill, New 654 Jersey. Economic Geology, 85: 1133-1161.

655 Johnson, C.A., and Skinner, B.J. 2003. Geochemistry of the Furnace Magnetite Bed,

656 Franklin, NewJersey, and the Relationship between Stratiform Iron Oxide Ores and 
657 Stratiform Zinc Oxide-Silicate Ores in the New Jersey Highlands. Economic Geology, 658 98: 837-854.

659 Johnston, P.J. 1996. The geological setting of the Hemlo Gold Deposit, Ontario, 660 Canada. PhD, Queen's University, Kingston, Ontario.

661 Kalczynski, M.J., and Gates, A.E. 2014. Hydrothermal alteration, mass transfer and 662 magnetite mineralization in dextral shear zones, western Hudson Highlands, New York, 663 United States. Ore Geology Reviews, 61: 226-247.

664 Klein, C. 2005. Some Precambrian banded iron-formations (BIFs) from around the 665 world; their age, geologic setting, mineralogy, metamorphism, geochemistry, and 666 origins. American mineralogist 90.10: 1473.

667 Large, R.R., Gemmell, J.B., and Paulick, H. 2001. The alteration box plot; a simple 668 approach to understanding the relationship between alteration mineralogy and 669 ithogeochemistry associated with volcanic-hosted massive sulfide deposits. Economic 670 Geology, 96: 957-971.

671 Leach, D.L., Sangster, D.F. et al., 2005. Sediment-hosted lead-zinc deposits: a global 672 perspective. Hedenquist J.W., Thompson J.F.H., Goldfarb R.J. et al.,eds.,Economic 673 Geology, One hundredth anniversary volume : 561-607.

674 McLelland, J., Morrison, J., Selleck, B., Cunningham, B., Olson, C., and Schmidt, K. 675 2002b. Hydrothermal alteration of late- to post-tectonic Lyon Mountain granitic gneiss, 676 Adirondack Mountains, New York; origin of quartz-sillimanite segregations, quartz-albite 
677 lithologies, and associated Kiruna-type low-Ti Fe-oxide deposits. Journal of

678 Metamorphic Geology, 20: 175-190.

679 McLelland, J.M. 1996. The Grenville Orogenic Cycle (ca. 1350-1000 Ma): An

680 Adirondack perspective. Tectonophysics, 265: 1-28.

681 McLelland, J.M., Foose, M.P., and Morrison, J. 2001. Kiruna-Type Low Ti, Fe Oxide

682 Ores and Related Rocks, Adirondack Mountains, New York: High-Temperature

683 Hydrothermal Processes. In Edited by T.B. Thompson. Society of Economic Geologists,

684 Littleton, CO, pp. 7-18.

685 McLennan, S.M. 1989. Rare earth elements in sedimentary rocks; influence of

686 provenance and sedimentary processes. Reviews in Mineralogy, 21: 169-200.

687 Pearce, J. A. 1996. A user's guide to basalt discrimination diagrams. In Trace element

688 geochemistry of volcanic rocks; applications for massive sulphide exploration.

689 Geological Association of Canada, Short Course Notes, 12(79), 113.

690 Peck, W.H., Volkert, R.A., Meredith, M.T., and Rader, E.L. 2006. Calcite-graphite

691 thermometry of the Frnaklin Marble, New Jersey Highlands. Journal of Geology, 114:

$692 \quad 485-499$.

693 Peck, W.H. 2009. Stable isotope and petrologic evidence for the origin of regional

694 marble-hosted magnetite deposits and the zinc deposits at Franklin and Sterling Hill,

695 New Jersey Highlands, United States. Economic Geology and the Bulletin of the Society

696 of Economic Geologists, 104: 1037-1054. 
697 Peter, J.M., and Goodfellow, W.D. 1996. Mineralogy, bulk and rare earth element

698 geochemistry of massive sulphide-associated hydrothermal sediments of the Brunswick

699 horizon, Bathurst mining camp, New Brunswick. Canadian Journal of Earth Sciences =

700 Revue Canadienne des Sciences de la Terre, 33: 252-283.

701 Puffer, J.H., and Volkert, R.A. 1991. Generation of trondhjemite from partial melting of

702 dacite under granulite facies conditions: an example from the New Jersey Highlands,

703 USA. Precambrian Research, 51: 115-125.

704 Puffer, J.H. 2001. Origin of Five Types of Proterozoic Magnetite Deposits in the New

705 Jersey Highlands. In Proterozoic Iron and Zinc Deposits of the Adirondack Mountains of

706 New York and the New Jersey Highlands Edited by J.F. Slack. Society of Economic

707 Geologists, Littleton, CO, pp. 103-104-110.

708 Rivers, T. 1997. Lithotectonic elements of the Grenville Province: review and tectonic

709 implications. Precambrian Research, 86: 117-154.

710 Smith, T.E., and Holm, P.E. 1990. The geochemistry and tectonic significance of pre-

711 metamorphic minor intrusions of the Central metasedimentary belt, Grenville Province,

712 Canada. Precambrian Research, 48: 341-360.

713 Spry, P., Peter, J., and Slack, J. 2000. Meta-exhalites as exploration guides to ore.

714 Reviews in Economic Geology, 11: 163-201. 
715 Sun, S.S., and McDonough, W.F. 1989. Chemical and isotopic systematics of oceanic

716 basalts; implications for mantle composition and processes. Geological Society Special

717 Publications, 42: 313-345.

718 Tollo, R.P., Bartholomew, M.J., Hibbard, J.P., and Karabinos, P.M., 2010. From Rodinia

719 to Pangea; the lithotectonic record of the Appalachian region. Geological Society of

720 America Memoir 206.

721 Valley, P.M., Hanchar, J.M., and Whitehouse, M.J. 2011. New insights on the evolution

722 of the Lyon Mountain Granite and associated Kiruna-type magnetite-apatite deposits,

723 Adirondack Mountains, New York State. Geosphere, 7: 357-389.

724 Volkert, R.A., and Drake, A.A.J. 1999. Geochemistry and stratigraphic relations of

725 Middle Proterozoic rocks of the New Jersey Highlands. U.S. Geological Survey, Reston, 726 Va.

727 Volkert, R.A. 2004. Mesoproterozoic rocks of the New Jersey Highlands, north-central

728 Appalachians: Petrogenesis and tectonic history. Geological Society of America

729 Memoirs, 197: 697-728.

730 Volkert, R.A., and Aleinikoff, J.N. 2007. 1.3Ga Continental-margin magmatic arc and

731 back-arc in the New Jersey Highlands and implications for the origin of zinc and iron ore

732 deposits. In Geological Society of America, Northeastern Section, 42nd annual meeting,

733 Durham, $\mathrm{NH}$. 
734 Volkert, R.A., Aleinikoff, J.N., and Fanning, C.M. 2010. Tectonic, magmatic, and

735 metamorphic history of the New Jersey Highlands: New insights from SHRIMP U-Pb

736 geochronology. Memoir-Geological Society of America, 206: 307-346.

737 Volkert, R.A. 2004. Mesoproterozoic rocks of the New Jersey Highlands, north-central

738 Appalachians; petrogenesis and tectonic history. Memoir-Geological Society of

739 America, 197: 697-728.

740 Volkert, R.A. 2011. Bedrock geologic map of the Wanaque quadrangel, Bergen, Morris

741 and Passaic counties, New Jersey. U.S. Geological Survey.

742 Winchester, J.A. and Floyd, P.A. 1984. The geochemistry of the Ben Hope Sill suite,

743 northern Scotland, U.K. Chemical Geology, 43:49-75

744 Winter, J.D. 2001. An Introduction to Igneous and Metamorphic Petrology. Prentice-

745 Hall, New Jersey.

746 Yang, K., and Scott, S. 2006. Magmatic Fluids as a Source of Metals in Seafloor

747 Hydrothermal Systems. In Back Arc Spreading Systems: Geological, Biological,

748 Chemical and Physical Interactions Edited by D.M. Christie, C.R. Fisher and Lee, S. \&

749 Givens, S. American Geophysical Union, Washington, D.C., 163-184 
METAVOLCANIC ROCKS

\begin{tabular}{|c|c|c|c|c|c|c|c|c|c|c|c|c|c|}
\hline \multirow[b]{3}{*}{ iviajuis } & \multicolumn{2}{|c|}{ TONALITIC GNEISS } & & & & \multirow{2}{*}{\multicolumn{2}{|c|}{$\begin{array}{l}\text { Felsic Interlayers } \\
\text { (Wanaque) }\end{array}$}} & & & & \multicolumn{3}{|c|}{ METAVOLCANIC ROCKS } \\
\hline & \multirow[b]{2}{*}{ R9 } & \multirow[b]{2}{*}{ R11 } & \multicolumn{3}{|c|}{ Cpx-Mc Gneiss (Warwick) } & & & \multicolumn{3}{|c|}{ K-rich Amphibolites (Warwick) } & & & \\
\hline & & & M3 & M5 & M7 & \multirow{2}{*}{$\begin{array}{l}\text { W26 } \\
\text { EDS }\end{array}$} & W7 & \multirow{2}{*}{ MDS } & M4 & M6 & R4 & R5 & R12 \\
\hline source & EDS & EDS & EDS & EDS & EDS & & MSU & & EDS & EDS & EDS & EDS & EDS \\
\hline $\mathrm{SiO} 2$ & 76.18 & 73.41 & 58.11 & 67.76 & 60.95 & 57.45 & 63.12 & 44.49 & 45.20 & 47.32 & 48.24 & 50.36 & 46.45 \\
\hline $\mathrm{TiO} 2$ & 0.21 & 0.34 & 0.48 & 0.42 & 0.22 & 2.69 & 0.54 & 1.50 & 1.53 & 1.69 & 1.47 & 1.00 & 1.18 \\
\hline $\mathrm{Al} 2 \mathrm{O} 3$ & 12.03 & 12.94 & 16.88 & 12.70 & 13.58 & 13.61 & 12.68 & 16.07 & 15.33 & 15.72 & 15.71 & 14.53 & 17.12 \\
\hline $\mathrm{Fe} 2 \mathrm{O} 3$ & 2.43 & 2.81 & 7.81 & 3.41 & 6.19 & 3.31 & 5.25 & 14.10 & 11.91 & 12.34 & 13.19 & 12.87 & 15.24 \\
\hline Mno & - & 0.07 & 0.18 & 0.14 & 0.25 & 0.08 & 0.31 & 0.42 & 0.40 & 0.11 & 0.28 & 0.20 & 0.27 \\
\hline $\mathrm{MgO}$ & 1.44 & 1.81 & 2.45 & 1.09 & 1.67 & 3.26 & 2.53 & 6.94 & 5.62 & 6.87 & 9.95 & 6.11 & 5.66 \\
\hline $\mathrm{CaO}$ & 2.80 & 3.28 & 4.02 & 2.58 & 5.52 & 12.60 & 7.62 & 8.41 & 11.33 & 5.06 & 6.13 & 7.81 & 8.29 \\
\hline $\mathrm{Na} 2 \mathrm{O}$ & 3.40 & 3.95 & 4.39 & 1.87 & 2.27 & 5.29 & 5.84 & 4.32 & 2.83 & 3.53 & 2.84 & 3.13 & 4.09 \\
\hline K2O & 1.42 & 1.20 & 5.37 & 9.88 & 9.19 & 0.20 & 1.74 & 2.78 & 3.81 & 5.69 & 1.99 & 3.17 & 1.40 \\
\hline P2O5 & 0.09 & 0.20 & 0.31 & 0.15 & 0.17 & 1.52 & 0.12 & 0.97 & 1.47 & 1.18 & 0.19 & 0.16 & 0.31 \\
\hline$S$ & - & - & - & - & - & 0.00 & - & - & - & - & - & 0.08 & - \\
\hline $\begin{array}{l}\mathrm{Cl} \\
\mathrm{LOI}\end{array}$ & - & - & - & - & - & 0.00 & - & - & 0.57 & 0.49 & - & 0.59 & - \\
\hline Total & 100.00 & 100.00 & 100.00 & 100.00 & 100.00 & 100.01 & 99.76 & 100.00 & 100.00 & 100.00 & 100.00 & 100.00 & 100.00 \\
\hline
\end{tabular}




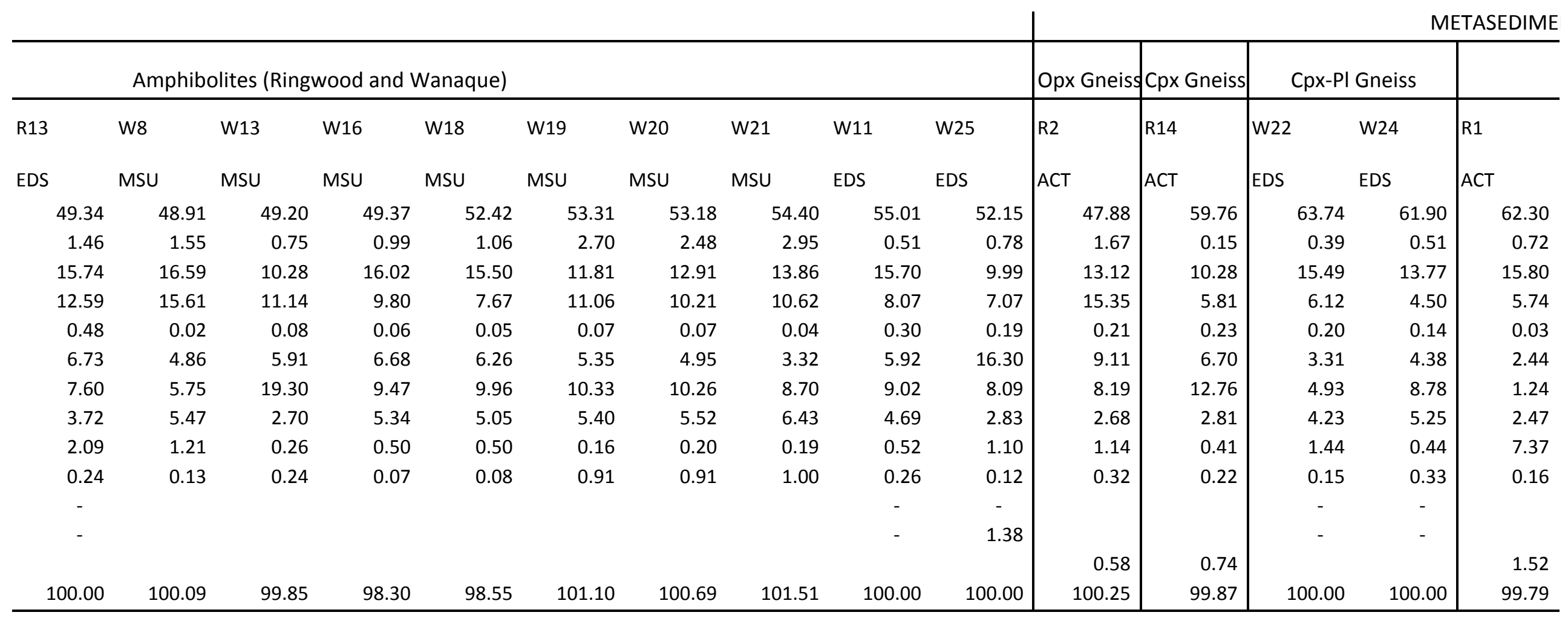




\begin{tabular}{|c|c|c|c|c|c|c|c|c|c|c|c|}
\hline \multicolumn{5}{|c|}{ NTARY ROCKS } & \multicolumn{7}{|c|}{ ORE AND ALTERED ROCKS } \\
\hline \multicolumn{3}{|c|}{ Bt-Qz Gniess } & \multicolumn{2}{|c|}{ Marble } & \multicolumn{3}{|c|}{ Amphibolites } & $\begin{array}{l}\text { QZ-DI } \\
\text { Gneiss }\end{array}$ & \multicolumn{2}{|c|}{ Massive Diopsidite } & \multirow{2}{*}{$\begin{array}{l}\text { Ore } \\
\text { w1 }\end{array}$} \\
\hline R16 & W4 & W10 & W5 & W6 & W15 & w9 & R8 & M1 & R15 & W2 & \\
\hline ACT & EDS & EDS & ACT & ACT & MSU & EDS & EDS & ACT & EDS & EDS & ACT \\
\hline 63.68 & 72.35 & 75.98 & 13.20 & 18.35 & 46.58 & 44.00 & 47.68 & 70.01 & 51.76 & 47.21 & 0.17 \\
\hline 0.87 & 0.61 & 0.92 & 0.04 & 0.01 & 0.93 & 3.40 & 2.33 & 0.07 & 0.18 & 0.21 & 1.23 \\
\hline 16.23 & 11.42 & 8.85 & 0.28 & 0.16 & 14.24 & 14.47 & 14.48 & 0.88 & - & - & 2.06 \\
\hline 5.86 & 5.75 & 3.37 & 3.55 & 2.54 & 10.36 & 15.00 & 14.00 & 8.72 & 12.29 & 13.75 & 98.54 \\
\hline 0.06 & 0.48 & 0.14 & 0.42 & 0.29 & 0.09 & 0.08 & 0.64 & 0.19 & 0.37 & 0.13 & 0.12 \\
\hline 2.94 & 2.17 & 3.25 & 17.72 & 23.71 & 8.72 & 5.30 & 5.64 & 6.28 & 13.48 & 14.52 & 0.50 \\
\hline 1.69 & 3.73 & 2.88 & 32.88 & 29.39 & 11.80 & 9.29 & 10.57 & 12.31 & 21.41 & 23.42 & $<0.01$ \\
\hline 3.87 & 1.83 & 2.28 & 0.03 & 0.04 & 4.22 & 5.91 & 3.28 & 0.42 & 0.43 & 0.69 & $<0.01$ \\
\hline 2.65 & 1.46 & 2.13 & 0.12 & 0.03 & 0.69 & 0.44 & 0.37 & 0.03 & - & - & $<0.01$ \\
\hline 0.09 & 0.20 & 0.19 & 0.03 & 0.02 & 0.07 & 0.37 & 0.72 & 0.05 & 0.09 & 0.06 & $<0.01$ \\
\hline & - & - & & & - & - & 0.28 & & - & - & \\
\hline & - & - & & & 1.43 & 1.73 & 0.01 & & - & - & \\
\hline 0.77 & & & 30.00 & 25.92 & & & & 0.15 & & & (2.83) \\
\hline 98.71 & 100.00 & 100.00 & 98.27 & 100.46 & 99.12 & 100.00 & 100.00 & 99.11 & 100.00 & 100.00 & 99.79 \\
\hline
\end{tabular}




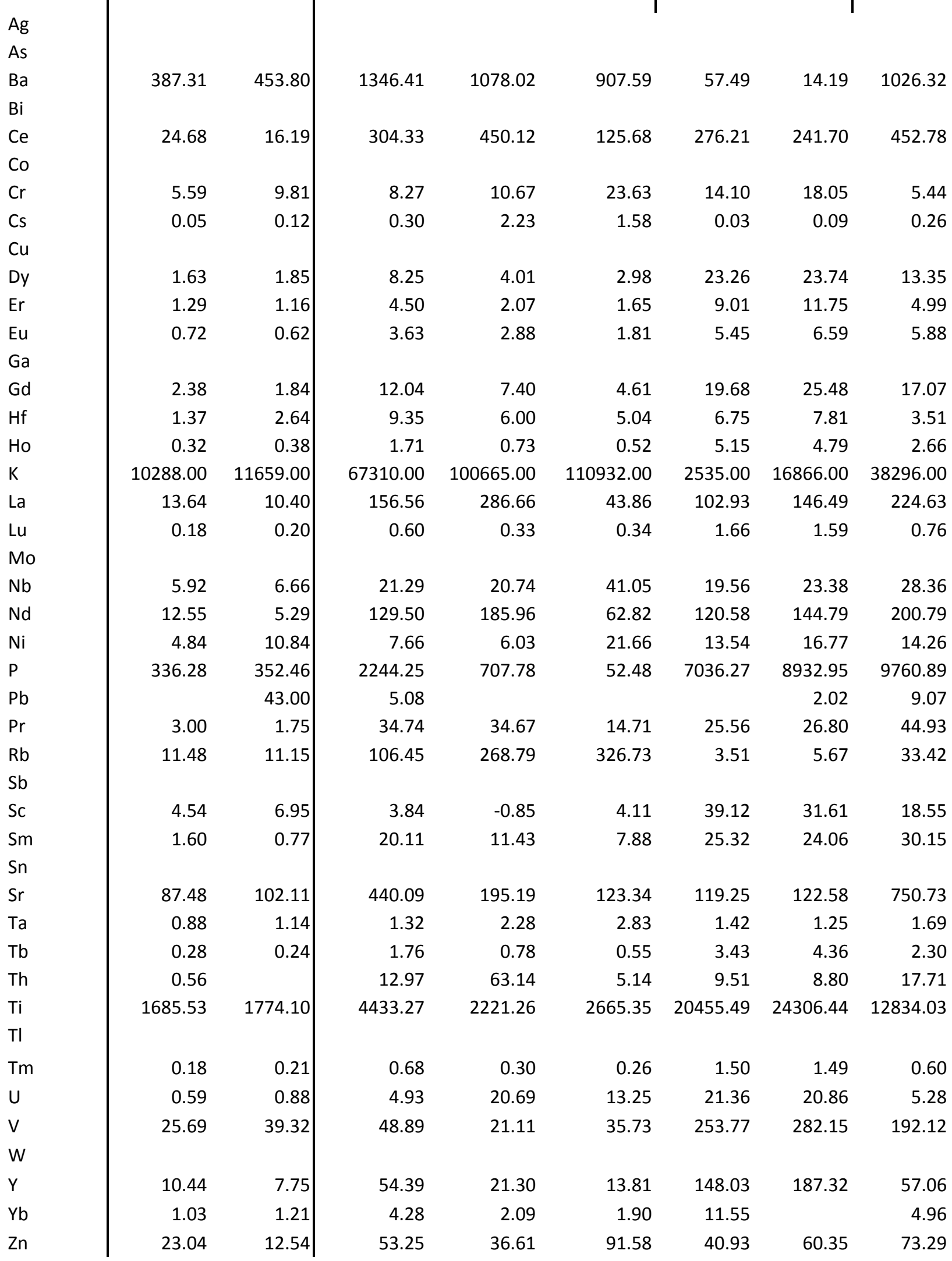


$\mathrm{Zr}$

47.99

85.20

422.09

208.08

194.00

188.88

236.02

133.61 
METAVOLCANIC ROCKS

\begin{tabular}{|c|c|c|c|c|c|c|c|c|c|}
\hline \multicolumn{2}{|c|}{ phibolites (Warwick) } & \multicolumn{8}{|c|}{ Amphibolites (Ringn } \\
\hline M4 & M6 & R17 & R18 & R19 & R4 & R5 & R12 & R13 & W8 \\
\hline 1406.40 & 1272.43 & 510.99 & 389.16 & 192.83 & & & 244.09 & & 87.12 \\
\hline 376.90 & 350.75 & 9.44 & 15.16 & 11.00 & 19.89 & 137.82 & 21.41 & 20.15 & 79.66 \\
\hline 7.01 & 5.30 & 109.76 & 202.11 & 232.50 & 121.46 & 72.10 & 140.24 & 146.06 & 91.85 \\
\hline 0.79 & 1.82 & & & & 0.56 & 1.14 & 0.76 & 1.23 & 0.24 \\
\hline 8.78 & 9.20 & 4.18 & 4.05 & 3.74 & 11.77 & 5.16 & 5.27 & 5.37 & 19.23 \\
\hline 3.50 & 3.56 & 2.30 & 2.34 & 2.11 & 4.84 & 2.50 & 2.87 & 2.62 & 7.83 \\
\hline 4.22 & 3.94 & 1.16 & 1.19 & 0.91 & 1.64 & 1.46 & 1.39 & 1.42 & 5.28 \\
\hline 12.65 & 12.73 & 3.74 & 3.60 & 3.45 & 7.98 & 4.77 & 4.49 & 4.52 & 16.01 \\
\hline 2.78 & 3.59 & 1.02 & 1.11 & 1.51 & 0.41 & 6.45 & 1.23 & 1.27 & 3.59 \\
\hline 1.71 & 1.77 & 0.87 & 0.84 & 0.79 & 2.54 & 1.11 & 1.19 & 1.20 & 3.56 \\
\hline 51536.00 & 70275.00 & & & & 21018.00 & 39554.00 & 16090.00 & 24739.00 & 13588.00 \\
\hline 197.13 & 186.00 & 3.10 & 8.18 & 3.59 & 6.60 & 69.14 & 5.85 & 7.31 & 60.22 \\
\hline \multirow{2}{*}{0.53} & 0.50 & 0.34 & 0.36 & 0.31 & 0.69 & 0.44 & 0.50 & 0.44 & 0.70 \\
\hline & & 0.95 & 0.61 & 0.40 & & & & & \\
\hline 16.44 & 16.20 & 1.47 & 1.10 & 3.59 & 4.24 & 18.84 & 2.77 & 3.35 & 5.82 \\
\hline 176.74 & 184.94 & 9.79 & 8.35 & 7.99 & 19.00 & 24.34 & 14.33 & 15.75 & 44.23 \\
\hline 42.27 & 15.27 & 78.06 & 65.82 & 96.97 & 88.24 & 38.50 & 57.16 & 66.24 & 85.69 \\
\hline 10606.04 & 7316.08 & 1132.50 & 941.85 & 438.80 & 558.73 & 841.36 & 1208.88 & 1248.92 & 449.59 \\
\hline 5.74 & & & & & 13.40 & 12.25 & & & 1.37 \\
\hline 36.39 & 34.60 & 1.93 & 1.99 & 1.84 & 3.61 & 7.49 & 3.11 & 3.33 & 10.82 \\
\hline 82.07 & 146.40 & 8.53 & 7.60 & 5.71 & 53.62 & 271.91 & 33.80 & 54.74 & 26.54 \\
\hline 10.99 & 9.66 & 18.82 & 24.43 & 13.98 & 29.86 & 22.25 & 36.92 & 39.66 & 20.14 \\
\hline 21.23 & 22.02 & 3.02 & 2.55 & 2.36 & 7.94 & 6.00 & 4.05 & 4.43 & 16.86 \\
\hline 500.78 & 702.87 & 192.99 & 257.29 & 138.68 & 53.71 & 125.94 & 181.88 & 183.44 & 366.70 \\
\hline 1.11 & 0.94 & 0.09 & 0.12 & 0.34 & 0.44 & 2.11 & 0.26 & 0.34 & 0.40 \\
\hline 1.58 & 1.64 & 0.65 & 0.63 & 0.60 & 1.54 & 0.75 & 0.82 & 0.75 & 3.29 \\
\hline 11.14 & 16.50 & & & & 0.30 & 14.51 & 0.12 & 0.30 & 1.01 \\
\hline 11228.87 & 10127.65 & 7279.03 & 7310.84 & 6848.17 & 5137.30 & 6377.52 & 6752.12 & 6778.23 & 8410.51 \\
\hline 0.52 & 0.52 & 0.37 & 0.35 & 0.33 & 0.67 & 0.40 & 0.49 & 0.42 & 0.93 \\
\hline 5.71 & 4.23 & bdl & 0.06 & 0.44 & 0.24 & 10.50 & 0.73 & 0.39 & 5.39 \\
\hline 186.62 & 168.90 & 239.54 & 251.70 & 235.78 & 251.01 & 150.04 & 248.76 & 244.89 & 913.55 \\
\hline 47.96 & 46.53 & 22.23 & 22.44 & 19.40 & 20.13 & 29.28 & 32.50 & 30.94 & 97.65 \\
\hline 3.07 & 3.22 & 2.37 & 2.37 & 2.15 & 5.79 & 2.79 & 3.12 & 2.96 & \\
\hline 88.19 & 86.28 & 69.47 & 59.60 & 49.26 & 74.85 & 37.47 & 132.77 & 76.97 & 24.59 \\
\hline
\end{tabular}




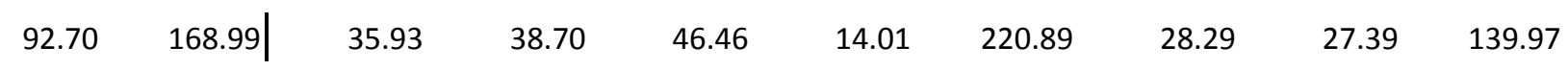




\begin{tabular}{|c|c|c|c|c|c|c|c|c|c|}
\hline \multicolumn{8}{|c|}{ vood and Wanaque) } & \multicolumn{2}{|r|}{ Opx G } \\
\hline W13 & W16 & W18 & W19 & W20 & W21 & $N 11$ & W25 & R20 & R21 \\
\hline 2.22 & 47.34 & 15.27 & 8.60 & 6.05 & 6.17 & 96.91 & 435.37 & 1147.16 & 1198.79 \\
\hline 56.73 & 22.05 & 13.30 & 39.94 & 53.24 & 48.76 & 44.72 & 55.99 & 15.95 & 14.82 \\
\hline 52.71 & 238.93 & 183.46 & 31.75 & 21.22 & 9.84 & 99.04 & 25.90 & 137.91 & 151.31 \\
\hline 0.08 & 0.10 & 0.09 & 0.13 & 0.12 & 0.10 & 0.12 & 0.18 & & \\
\hline 5.07 & 5.94 & 4.12 & 7.80 & 10.83 & 10.15 & 4.71 & 7.82 & 0.43 & 1.14 \\
\hline 3.10 & 3.21 & 2.35 & 4.00 & 5.46 & 5.03 & 2.65 & 4.35 & 0.35 & 0.67 \\
\hline 1.10 & 1.09 & 0.97 & 1.72 & 2.32 & 2.16 & 1.05 & 1.51 & 0.87 & 0.83 \\
\hline 5.07 & 5.03 & 3.63 & 7.34 & 10.29 & 9.43 & 5.42 & 7.30 & 2.11 & 2.44 \\
\hline 4.51 & 1.98 & 2.16 & 2.58 & 2.41 & 2.02 & 0.94 & 2.36 & 0.86 & 0.63 \\
\hline 1.11 & 1.25 & 0.89 & 1.60 & 2.22 & 2.08 & 0.99 & 1.71 & 0.09 & 0.24 \\
\hline 2882.00 & 4935.00 & 3696.00 & 1708.00 & 1253.00 & 1025.00 & 8436.00 & 30142.00 & & \\
\hline 20.32 & 11.06 & 5.30 & 18.72 & 23.65 & 20.29 & 18.04 & 25.00 & 8.04 & 6.85 \\
\hline \multirow[t]{2}{*}{0.65} & 0.43 & 0.36 & 0.56 & 0.72 & 0.66 & 0.40 & 0.58 & bdl & 0.03 \\
\hline & & & & & & & & 0.41 & 0.49 \\
\hline 5.67 & 3.76 & 5.73 & 12.89 & 15.31 & 17.31 & 3.12 & 13.70 & 7.83 & 4.67 \\
\hline 20.69 & 17.62 & 11.39 & 25.47 & 35.17 & 29.58 & 27.55 & 31.69 & 6.04 & 6.68 \\
\hline 54.57 & 54.77 & 40.75 & 19.90 & 20.64 & 32.30 & 58.82 & 15.23 & 98.97 & 108.51 \\
\hline 988.26 & 243.14 & 284.11 & 3138.12 & 4129.67 & 4292.92 & 1672.69 & 567.71 & 723.68 & 961.62 \\
\hline 1.18 & 1.09 & 1.33 & 1.26 & 1.19 & 1.36 & 1.15 & 1.03 & & \\
\hline 6.88 & 3.75 & 2.31 & 5.82 & 7.97 & 6.84 & 6.25 & 7.45 & 1.79 & 1.71 \\
\hline 9.89 & 6.40 & 6.45 & 7.50 & 5.32 & 6.23 & 5.08 & 40.11 & 129.13 & 59.89 \\
\hline 20.15 & 35.31 & 34.89 & 31.85 & 32.73 & 27.68 & 38.33 & 15.34 & 6.26 & 11.39 \\
\hline 4.65 & 4.42 & 3.11 & 6.78 & 9.63 & 8.60 & 6.16 & 8.52 & 0.96 & 1.49 \\
\hline 24.46 & 107.94 & 90.97 & 80.29 & 78.73 & 124.72 & 363.05 & 75.05 & 57.17 & 48.13 \\
\hline 0.33 & 0.22 & 0.28 & 1.59 & 1.06 & 1.27 & 0.53 & 1.62 & 0.40 & 0.29 \\
\hline 0.85 & 0.96 & 0.66 & 1.31 & 1.85 & 1.74 & 0.86 & 1.33 & 0.24 & 0.32 \\
\hline 2.53 & 1.00 & 0.70 & 3.37 & 3.94 & 2.36 & -0.33 & -1.57 & & \\
\hline 4008.95 & 5582.67 & 6222.80 & 12997.28 & 14004.92 & 15291.65 & 5474.44 & 4372.87 & 10181.45 & 9970.94 \\
\hline 0.47 & 0.45 & 0.35 & 0.54 & 0.71 & 0.65 & 0.41 & 0.67 & bdl & 0.03 \\
\hline 4.85 & 0.16 & 0.10 & 0.52 & 0.60 & 0.48 & 0.27 & 0.50 & 0.19 & 0.18 \\
\hline 134.75 & 192.32 & 214.71 & 214.53 & 187.81 & 131.77 & 258.34 & 56.77 & 197.74 & 255.80 \\
\hline \multirow[t]{2}{*}{34.91} & 33.47 & 23.09 & 43.77 & 78.05 & 75.50 & 31.59 & 43.41 & 0.43 & 5.03 \\
\hline & & & & & & 2.54 & 4.21 & bdl & 0.14 \\
\hline 32.46 & 31.69 & 22.59 & 41.84 & 45.01 & 43.25 & 87.47 & 17.44 & 18.65 & 26.47 \\
\hline
\end{tabular}


167.81

73.83

73.50

48.76

46.04

39.19

25.16

76.18

36.50

28.16

$\mid$

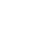


METASEDIMENTS

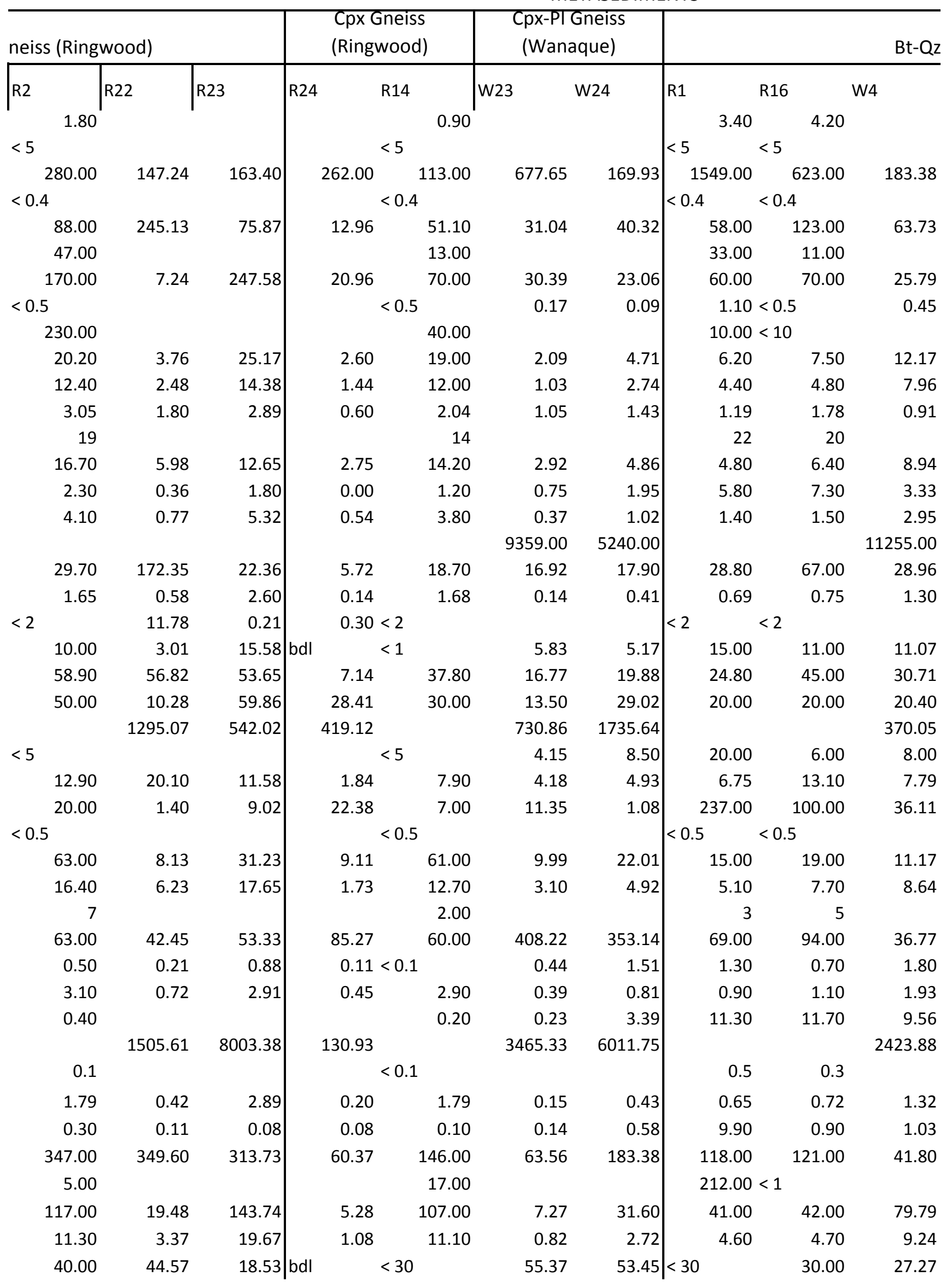


$\begin{array}{lll}80.00 & 6.89 & 37.61 \\ & & \end{array}$ 


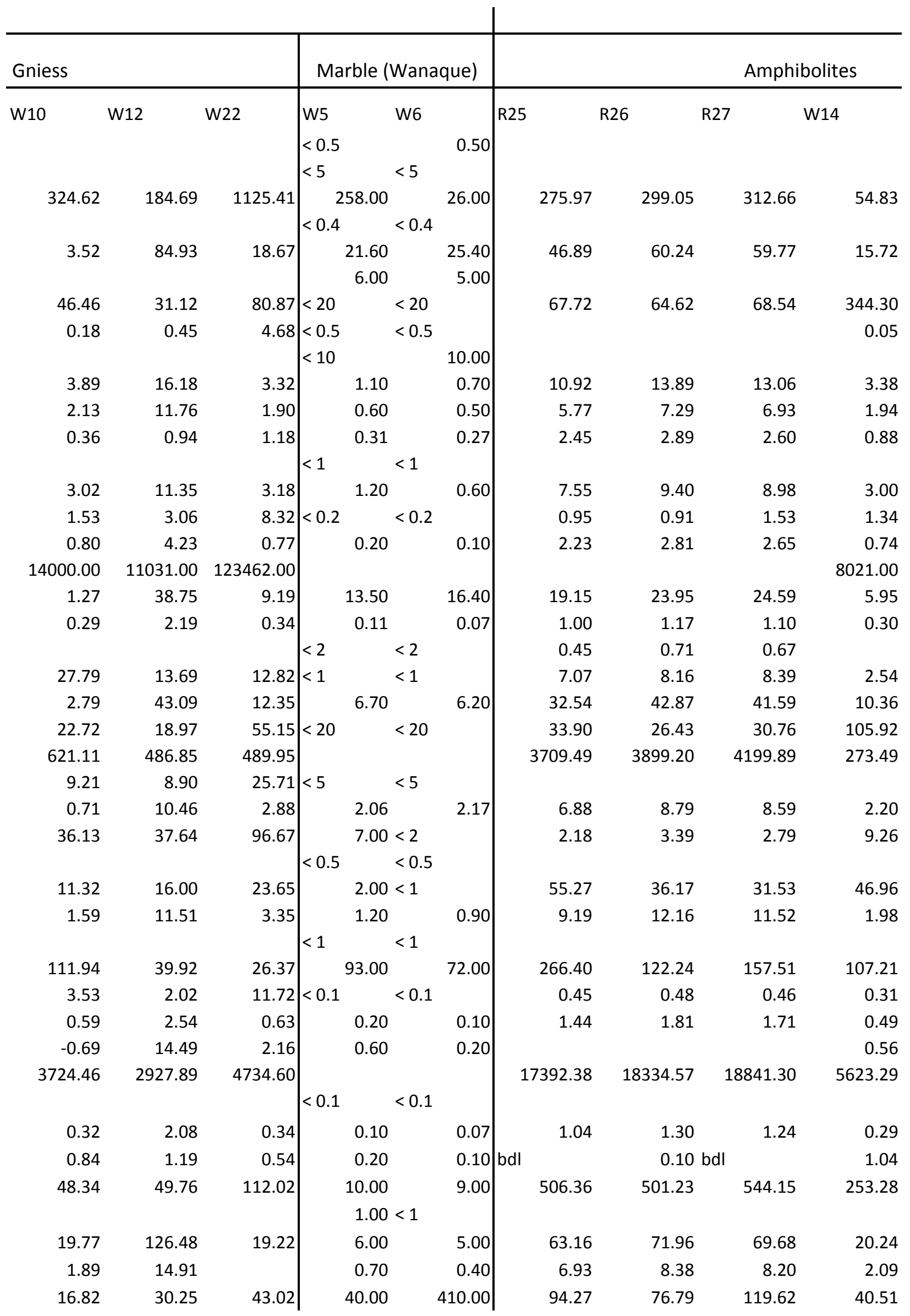


48.02

95.31

42.05

5.00

5.00

16.84

20.33

27.14

49.83

https://mc06.manuscriptcentral.com/cjes-pubs 
ORE AND ALTERED ROCKS

\begin{tabular}{|c|c|c|c|c|c|c|c|}
\hline & & $\begin{array}{l}\text { Qz-DI } \\
\text { Gneiss }\end{array}$ & Massive & Diopsidite & & Ore & \\
\hline w9 & R7 & M1 & R15 & W3 & w2 & R6 & R10 \\
\hline & & 0.80 & & & $<0.5$ & & \\
\hline & & $<5$ & & & $<5$ & & \\
\hline 67.80 & 167.09 & 13.00 & 16.00 & -6.85 & $<3$ & 38.18 & 43.53 \\
\hline & & $\mid<0.4$ & & & $\mid<0.4$ & & \\
\hline 51.46 & 41.61 & 47.90 & 45.86 & 21.75 & 0.20 & 211.00 & 23.79 \\
\hline & & 26.00 & & & 89.00 & & \\
\hline 89.94 & 55.98 & $<20$ & 37.51 & 23.36 & 50.00 & 7.22 & 11.00 \\
\hline 0.13 & 0.04 & $<0.5$ & 0.26 & 0.12 & $<0.5$ & 0.04 & 0.01 \\
\hline & & 110.00 & & & $<10$ & & \\
\hline 10.86 & 9.78 & 1.80 & 10.40 & 2.65 & $<0.1$ & 2.61 & 0.97 \\
\hline 5.97 & 4.30 & 0.90 & 6.39 & 1.61 & $<0.1$ & 1.44 & 0.98 \\
\hline 2.43 & 2.16 & 1.02 & 1.02 & 0.65 & $\mid<0.05$ & 1.61 & 0.23 \\
\hline & & 3 & & & 56.00 & & \\
\hline 10.13 & 7.83 & 2.40 & 8.01 & 2.71 & $<0.1$ & 12.86 & 1.69 \\
\hline 5.66 & 1.05 & 0.30 & 0.95 & 0.90 & $<0.2$ & 0.05 & 0.10 \\
\hline 2.41 & 2.22 & 0.30 & 2.42 & 0.54 & $<0.1$ & 0.32 & 0.16 \\
\hline 7730.00 & 8090.00 & & & & & & 798.00 \\
\hline 19.65 & 15.69 & 18.80 & 13.11 & 5.78 & $<0.1$ & 192.73 & 11.64 \\
\hline 0.83 & 0.71 & 0.16 & 1.22 & 0.29 & $<0.04$ & 0.11 & 0.14 \\
\hline & & $<2$ & & & $<2$ & 19.00 & \\
\hline 14.14 & 7.00 & $<1$ & -0.39 & -0.64 & $<1$ & 5.39 & 10.71 \\
\hline 36.35 & 27.90 & 26.10 & 31.17 & 10.88 & $<0.1$ & 93.17 & 8.81 \\
\hline 38.10 & 59.75 & $<20$ & 23.65 & 22.51 & 70.00 & 23.05 & 21.69 \\
\hline 1447.08 & 3655.65 & & 46.71 & 105.74 & & 905.01 & 288.35 \\
\hline 2.34 & & 7.00 & 1.45 & -0.93 & $<5$ & 1088.00 & 1393.00 \\
\hline 7.63 & 6.57 & 6.47 & 7.06 & 3.09 & $<0.05$ & 30.64 & 2.20 \\
\hline 6.66 & 2.04 & 4.00 & 6.04 & -1.01 & $<2$ & 1.30 & 1.28 \\
\hline & & $<0.5$ & & & $<0.5$ & & \\
\hline 42.38 & 58.63 & 2.00 & 43.12 & 16.16 & $<1$ & 2.22 & 3.48 \\
\hline 11.10 & 7.66 & 4.60 & 9.08 & 2.04 & $<0.1$ & 16.08 & 0.52 \\
\hline & & 4 & & & 4.00 & & \\
\hline 157.72 & 128.39 & 17.00 & 8.39 & 20.89 & $<2$ & 6.82 & 3.78 \\
\hline 1.14 & 0.73 & $<0.1$ & 0.48 & 0.30 & $<0.1$ & 0.74 & 0.80 \\
\hline 1.89 & 1.36 & 0.30 & 1.68 & 0.44 & $<0.1$ & 0.63 & 0.18 \\
\hline 0.93 & 0.84 & 0.70 & -0.72 & -0.17 & $<0.1$ & 6.64 & 0.47 \\
\hline 17015.58 & 17490.30 & & 800.09 & 865.33 & & 7276.19 & 1833.74 \\
\hline & & $<0.1$ & & & $<0.1$ & & \\
\hline 0.92 & 0.69 & 0.13 & 1.07 & 0.26 & $<0.05$ & 0.12 & 0.14 \\
\hline 0.81 & 0.44 & 2.10 & 0.58 & 0.56 & $<0.1$ & 1.10 & 0.89 \\
\hline 310.28 & 499.62 & 45.00 & 98.89 & 109.12 & 1608.00 & 1348.37 & 787.79 \\
\hline & & $<1$ & & & 20.00 & & \\
\hline 63.23 & 57.26 & 9.00 & 66.62 & 12.31 & $<2$ & 10.84 & 5.75 \\
\hline 5.75 & 4.66 & 0.90 & 7.70 & 1.71 & $<0.1$ & 0.61 & 0.82 \\
\hline 56.28 & 111.77 & 110.00 & 43.11 & 21.55 & 120.00 & 177.68 & 103.86 \\
\hline
\end{tabular}

https://mc06.manuscriptcentral.com/cjes-pubs 
$153.00 \quad 22.27|\quad 16.00| \quad 24.82 \quad 42.41|<4 \quad 0.64 \quad 8.06|$ 
